\title{
Fen Bilgisi Öğretmen Adaylarının Bilimsel Araştırma Yöntemlerini Kullanma Durumlarının Değerlendirilmesi
}

\author{
Evaluation of the Pre-service Science Teachers'Usage of \\ Scientific Research Methods
}

\author{
Gülfem MUŞLU KAYGISIZ*, Elif BENZER**, Canan DİLEK EREN***
}

\begin{abstract}
Öz: Bu çalışmanın amacı, fen bilgisi öğretmen adaylarının fen eğitimi alanında kendi belirledikleri bir problemden hareketle eğitimde bilimsel araştırma yöntemlerini ne düzeyde kullandıklarını belirlemektir. Bu amacı gerçekleştirmek için çalışma temelde nicel araştırma yöntemlerinden tarama deseni çerçevesinde düzenlenmiştir. Bununla birlikte öğretmen adaylarının raporları betimsel çözümlemeler ile de örneklendirilmiştir. Çalışma uygun örnekleme yöntemiyle seçilen 64 fen bilgisi öğretmen adayı ile yürütülmüștür. Çalışmada veriler öğretmen adaylarının hazırladıkları 15 araştırma raporu ile toplanmış, araştırmacılar tarafindan geliştirilen "Bilimsel araştırma yöntemini kullanma becerileri rubriği" ile de değerlendirilmiştir. Yapılan değerlendirme sonucunda öğretmen adaylarının en çok; başlık, biçim, özet, dil ve anlaşılırlık bağlamında ele alınan genel görünüş, araştırmanın amacının belirtilmesi, veri toplama araçlarının ve değerlendirme yöntemlerinin çalışmaya uygunluğu, bulgular kısmı, araștırma sorularına göre sonuçların yapılandırılması kısımlarında başarılı oldukları görülmüştür. Öğretmen adaylarının başarılı olamadıkları kısımlar ise; alanyazında kullanılan kaynakların eleştirel bir bakış açısıyla incelenerek yazılması, çalışmanın öneminin belirtilmesi, geçerlik ve güvenirlik çalışmalarının belirtilmesi, sonuçların kaynaklarla tartışılması, yeni önerilerin geliştirilmesi ve kaynakların doğru kullanımıyla ilgili kısımlardır. Anahtar Kelimeler: Bilimsel araştırma yöntemleri, fen bilgisi öğretmen adayları, fen eğitimi
\end{abstract}

\begin{abstract}
The aim of this study is to determine to what extend pre-service science teachers use scientific research methods in classroom activities they prepared. The study was carried out with 64 pre-service science teachers who were selected by incidental sampling method. Quantitative research methods were used in the analysis. In addition to these, descriptive analysis was used to analyze teacher candidates' reports. The reports were collected from 15 pre-service teachers and evaluated with the "Scientific research method rubric" which was developed by the researchers. It was found that most of the teacher candidates were successful in determining the title, form, abstract, language and general view, taken in the context of understandability, specifying the purpose of the research, choosing the appropriate data collection tools and evaluation methods, stating the findings according to the research questions. However, analyzing the previous literature critically, citing the references appropriately, stating the importance of the study and the validity and reliability of the research, discussing the results by comparing them with the previous studies, and suggesting further studies are the areas the teachers need further assistance.
\end{abstract}

Keywords: Pre-service science teachers, science education, scientific research methods

\section{Giriş}

Fen eğitiminde bilim ve bilimsel kavramların önemi sadece kavram, teori ve yasalardan oluşan bilimsel bilgiyle değil; üreten, sorgulayan, problem çözen bireyler için, teori ve yasaların nasıl oluşturulduğuyla ağırlık kazanmaktadır. Bireylerin dolayısı ile toplumların bilime yönelik yaklaşımları da ülkelerin yaşam standartlarını arttırmaktadır. $\mathrm{Bu}$ nedenle ulusal fen programlarında bilimsel bilginin elde edilmesi için bilimsel süreçler giderek önem

\footnotetext{
*Dr. Öğrt.Üye.Hasan Kalyoncu Üniversitesi Eğitim Fakültesi, Gaziantep-Türkiye, ORCID: 0000-0003-3286-0454, eposta: gulfem.muslu@hku.edu.tr

** Doç. Dr. Marmara Üniversitesi Atatürk Eğitim Fakültesi, İstanbul-Türkiye, ORCID: 0000-0002-2518-7681,e-posta: elif.benzer@marmara.edu.tr

*** Doç. Dr. Kocaeli ÜniversitesiEğitim Fakültesi, Kocaeli-Türkiye, ORCID: 0000-0002-7004-5066, e-posta: canandilek@kocaeli.edu.tr
} 
kazanmaktadır. Türkiye Yükseköğretim Yeterlikler Cerçevesine (Yüksek Öğretim Kurulu [YÖK], 2020) göre de öğretmen yetiştirme ve eğitim bilimleri temel alan yeterlikleri içerisinde bilgi, beceri ve yetkinlik boyutlarının tümünde bilimsel bilginin elde edilmesi ve/ya bilimsel yöntemin kullanılmasına ilişkin maddeler yer almaktadır. Bu da öğretmen yetiştirmede bu özelliklerin önemini göz önüne sermektedir. Fen bilimleri dersi öğretim programında öğrencilere kazandırılması istenen bilimsel süreç becerilerini kazanmalarına rehberlik edecek olan öğretmenlerin bilimsel bilginin kullanılması, yeni bir bilimsel bilgi oluşturulurken uygun yöntemin belirlenmesi, yeni bilimsel bilginin oluşturulması ve paylaşılması aşamalarını bilim etiği çerçevesinde oluşturması da bu kapsamda değerlendirilmelidir. Yapılan bir araştırma öğretmen adaylarının (bilime ilişkin) sahip oldukları inanışları doğrultusunda ders planlarını tasarladıklarını ve öğretimi gerçekleştirmeye çalıştıklarını göstermektedir (Palmquist ve Finley, 1997). Batı (2013) etkili bir bilim eğitiminin, öğrencilerin özgür, saçma veya akıldış1 fikirler üretebildikleri ve bilgiye ulaşmada belli bir yönteme bağlı kalmadan kendilerinin geliştirdikleri yöntemlerle çözüme ulaşabildikleri bir ortamın sağlanması ile mümkün olabileceğini belirtmiştir. Bu bağlamda; öğretmenlerin öğrencilerine bilimi en iyi şekilde öğretmelerinde kendilerinin de bilimi anlamalarını sağlayacak en önemli etkenin uygulama olduğu düşünüldüğünde bilimsel araştırma yöntemlerini bir araştırmacı özelliklerine sahip öğretmenler olarak tasarlamaları önemli bir adım olarak görülebilir. Buradan hareketle bu kısımda bilimsel araştırmanın ne olduğu ve hangi aşamalarla uygulanabileceğine yönelik alanyazın taramasına yer verilmiştir.

Creswell'e (2012) göre bilimsel araştırmalar, bir taraftan eğitimde var olan boşlukları doldurarak ya da daha önceki çalışmalara ek sonuçlar sunarak eğitim paydaşlarının bilgi birikimine katkı sağlayıp uygulamaya yönelik gelişmeleri ortaya koyarak daha nitelikli bir eğitim ortamı oluşturmalarına katkı sağlarken, diğer taraftan bakanlık çalışanları ya da okul yöneticileri gibi karar mercii olan kişilere ortaya koyduğu bilimsel verilerle daha doğru karar vermeleri yönünde destek olmaktadır.

$\mathrm{Bu}$ açıdan bakıldığında bilimsel bir araştırma sürecini yürütme ve bilimsel yöntemi kullanma sadece öğretim üyeleri için önemli bir beceriymiş gibi atfedilse de çoğu eğitimci, okul idarecisi, lisansüstü öğrencileri gibi diğer paydaşlarında bu araştırmalardan yararlandıkları görülmektedir.

Bilimsel araştırmalarda kullanılan bilimsel yöntem için yapılan tanımlar incelendiğinde; "Bilginin geçerli ve güvenilir yollarla sistematik ve düzenli olarak elde edilmesi uğraşı ve bu uğraşın bilimsel bir yolla sürdürülmesi (Yolcu, 2009, s. 12)" ve "bilimsel araştırmada gerçeğe ulaşmak için izlenen yol veya süreç (Seyidoğlu, 2009, s. 1)" tanımlarında olduğu gibi bilimsel bilgiye ulaşmak için uygulanan yol olarak tanımlanabilmektedir. Ayrıca "Problemin hangi yolla çözüleceği, çözüme uygun tekniklerin neler olduğu, araştırmanın hangi yaklaşımla ele alındığ yöntemle açıklanır (Yazıcıoğlu ve Erdoğan, 2011, s. 65)" ve "Problemi çözerken 'izlenecek yol' anlamına gelen bilimsel yöntemin bir bilim insanının bilişsel süreçleriyle ilgili yönü, bir de doğrulama yönü vardır (Erkuş, 2011, s. 36)" tanımlarında görüldüğü gibi problem çözmeye vurgu yapan tanımlamaları mevcuttur. Bazı diğer tanımlamalarda ise sadece yönteme ve yöntem basamaklarına vurgu yapılabilmektedir. Bu tanımlardan biri Creswell'in (2012) bilimsel yöntemin altı adımını sıraladığı şu tanımıdır: Bilimsel yöntem, altı adımdan oluşan bir araştırma sürecidir. $\mathrm{Bu}$ adımlar; Araştırma probleminin tanımlanması, alanyazın taraması, araştırma amacının belirlenmesi, verilerin toplanması, verilerin analizi ve yorumlanması ve araştırmanın raporlanması ve değerlendirilmesidir.

$\mathrm{Bu}$ adımlar araştırmanın çeşidi ne olursa olsun, her araştırmada bilimsellik adına uyulması gereken ortak özelliklerdir (Düztepe, 2004). Bilimsel bir araştırmanın yürütülmesinde kullanılan bu adımlar aşağıda ayrıntılı olarak ele alınmıştır.

Bilimsel yöntem bir problemin tanımlanmasıyla başlamaktadır. Burada problem ve araştırma problemi arasındaki ayrımı yapmak gerekir. Problem "bireyi fiziksel ya da düşünsel yönden rahatsız eden, kararsızlık ve birden çok çözüm yolu olasılığı görülen her durum (Karasar, 1991, s. 28)" ya da "Giderilmek istenen her güçlük (Genç, 2013, s. 82)" şeklinde tanımlanabilir. Araştırma problemi ise çoğu kaynakta; çözümlenmesi ya da yanıt aranması gereken bir sorun olarak tanımlanmıştır (Arıkan, 2013; Büyüköztürk, Kılıç Çakmak, Akgün, Karadeniz ve Demirel, 
2018; Erkuş, 2011; Sönmez ve Alacapınar, 2011). Bununla birlikte araştırma problemi Özdamar (2003, s. 60) tarafından "araştırıcıyı yönlendiren, karara ulaştıran doğru ve geçerli yolları bulmasını sağlayan yardımcı düşüncelerdir" şeklinde tanımlanmıştır. Bazı tanımlamalarda problemin ifade olarak belirtilmesi ön plana çıkarılmıştır. Örneğin; Şencan (2006, s. 17) "Problem cümlesi araştırma sorununun iki üç satır halinde ifade edilmesinden ibarettir" ve Yazıcıoğlu ve Erdoğan (2011, s. 62) "Araş̧ırmanın amacının soru cümlesi şeklinde yazılması araştırmanın problem cümlesi olarak tanımlanır” şeklinde ifade etmişlerdir. Ekiz (2009) ve Creswell (2012) problem durumu ya da problem ifadesi şeklinde bir başlık altında yapılması gerekenleri ifade etmişlerdir. Creswell (2012) 'problem ifadesi' olarak adlandırdığ 1 bölümde; ele alınan konu, problem, problemin gerekçeleri ve öneminin ortaya konmaya çalışıldığını belirtmiştir.

İlgili alanyazın taraması; araştırma probleminin anlamlı olabilmesi için konunun hangi bağlamda ele alındığ 1 , daha önce hangi araştırmaların yapıldığı, alanda nasıl eksikliğin bulunduğu ve yapılan çalışmanın hangi yönüyle/yönleriyle önemli olduğu bilgilerinin bulunduğu bölüm olarak karşımıza çıkmaktadır. Bu bölümde alanyazının farklı bakış açılarıyla ve tüm yönleriyle tartışılması/verilmesi önemlidir. Creswell (2012) konuyla ilgili daha önce yapılan yayınların tespit edilmesi, değerlendirmeye dahil edilen alanyazının özenle seçilmesi ve alanyazının yazılı bir rapor halinde sunulmasını literatür/alanyazın taraması olarak tanımlamıştır.

Alanyazın taraması ve problem ifadesi ile şekillenen araştırmanın amacı Creswell (2012) tarafından "araştırmanın niyetini ortaya koyan, araştırma konusunun kapsamına odaklanan problemin yeniden ifade edilmiş biçimidir" şekilde tanımlanmıştır. Problem cümlesine göre şekillenebilen bir diğer kavram ise hipotezdir. Hipotez, araştırılan problemle ilgili olarak öne sürülen (Arıkan, 2013; Bal, 2009; Seyidoğlu, 2009) olaylar ya da olgular arasındaki ilişkileri açıklamak için kurulan (Bal, 2009; Büyüköztürk ve diğerleri, 2018; Karasar, 1998), henüz doğrulanmamış (Büyüköztürk ve diğerleri, 2018; Dura, 2005) geçici olarak kabul edilen ve gerçekleşmesi beklenen önermelerdir (Bal, 2009; Özdamar, 2003). Bir hipotez cümlesinde bağımlı ve bağımsız değişkenlere yer verilebilir. Bağımlı değişken, bir araştırmada diğer değişkenlerce etkilenip değişik değerler alan değişkene denir. Bağımsız değişken ise bir araştırmada neden değişkenine denir. Sonucu etkileyip etkilemediği araştırılan değişkendir (Sönmez ve Alacapınar, 2011).

Bilimsel bir araştırmanın giriş bölümünde bulunan diğer ifadeler çalışmanın sınırlılıkları ve çalışmada kabul edilen sayıltılar kısımlarıdır. Sınırlılıklar; "araştırmacının, araştırmanın temeli, uygulanması ve sonuçları açısından sınırlarını belirlediği (Kaya ve Şahin, 2013, s. 6)" ve "normal olarak yapmak isteyip de çeşitli nedenlerle vazgeçmek zorunda kaldığı (Karasar, 1998, s. 73)" ifadeler olarak tanımlanır. Gerekçeli olarak veri, kaynak, güçlük, zaman, varsa maliyet sinırlamaları ve benzeri durumlar bu kısımda belirtilir (Aziz, 2018). Sayıltılar, araştırmada doğruluğunun kanıtlanmasına gerek görülmeyen ve doğruymuşçasına kabul edilen ifadeler ya da yargılardır (Büyüköztürk ve diğerleri, 2018; Karasar, 1998).

Bilimsel bir araştırmada giriş kısmının (alanyazın, problem durumu, amaç, hipotez, sinırlılık ve sayıltılar) ardından yöntem kısmı gelmektedir. Yöntemde araştırmada izlenen yol (desen), üzerinde inceleme yapılan bütün ya da bütünün parçası (örneklem, evren, çalışma grubu), verilerin toplanması ve değerlendirilmesi aşamaları bulunmaktadır.

Bilimsel bir çalışmanın modeli; yaklaşım, desen, tasarım (Genç, 2013) veya araştırma geleneği, araştırma yaklaşımı, araştırma stratejisi gibi kavramlarla da kullanılmaktadır (Kaya ve Şahin, 2013). Model, bir araştırmanın problemini çözmek için veya hipotezini test etmek için veri toplama ve değerlendirme yollarını gösteren plandır (Balc1, 2015; Kaya ve Şahin, 2013). Bir araştırmada evren, araştırma probleminin kapsamına giren veya sonuçların genellenmesi istenilen grup, örneklem ise evreni temsil edebilecek ve evrenden seçilen verilerin toplandığ 1 evrenin sınırlı bir parçası olarak tanımlanabilir (Arıkan, 2013; Bal, 2009; Büyüköztürk ve diğerleri, 2018; Karasar, 1998; Sönmez ve Alacapınar, 2011). Örneklemden verilerin toplanması, araştırma hipotezi veya sorularına/probleme cevap bulmak için farklı yöntemlerle doğru bilgi toplamak olarak tanımlanabilir (Creswell, 2012). Bu verilerin toplanması için araştırmanın özelliğine göre farklı veri toplama tekniklerinden yararlanılabilir (anket, gözlem, görüşme, yazışma, belgesel tarama) (Cemaloğlu, 2009). Fakat veri toplama teknikleri için genel bir gruplandırma yapılacak 
olursa iki farklı gruptan söz edilebilir. Bunlar; görüşme, anket, gözlem, uygulama gibi birinci elden veri toplama teknikleri ve kitap, tez, süreli yayınlar gibi ikinci elden yani başkaları tarafından yazılan verileri toplama teknikleridir (Seyidoğlu, 2009). Araştırmada hangi tür verilerin hangi kaynaklardan, hangi tekniklerle veya hangi araçlarla, kimlerce ve ne zaman toplandığı açıkça belirtilmelidir. Veri toplamak için anket, ölçek ve benzeri araçlar kullanılmışsa bunların amaçlarının ne olduğu, nasıl ve kimlerce geliştirildikleri, geçerlik ve güvenirliklerinin bilinip bilinmediği verilerin toplanması bölümünde yapılır (Karasar, 1991). Bu noktada geçerlilik; veri toplama aracının ölçme amacına uygunluğunu yani ölçmek istediği niteliği ölçme derecesini gösterir (Aziz, 2018; Karasar, 1991; Sönmez ve Alacapınar, 2011). Verilerin güvenirliği ise; bulguların gerçeği yansıtma derecesi (Ekiz, 2009; Saruhan ve Özdemirci, 2011), ölçümlerin tesadüfi hatalardan arınma derecesi (Balc1, 2015) ve farklı zaman, mekan veya kişilerle de yapılsa da ölçüme sonuçlarının tutarlılık göstermesi olarak tanımlanır (Arıkan, 2013; Ekiz, 2009; Gürsakal, 2001).

Verilerin çözümlenmesi; toplanan verilerin nasıl parçalara ayrıldığı ve özetlendiği; tablo, resim ve şekillerle nasıl bir araya getirilerek betimleme yapıldığ 1 ve bu sonuçların nasıl yazılı olarak sunulduğu hakkında açıklama yapıldığı kısımdır (Creswell, 2012). Bu kısımda verilerin sunulması genellikle tablo ve şekillerle olabildiği gibi bazen verilerden direkt yazılı alıntılarla da yapılabilir. Bir araştırmanın raporlaştırma kısmı ise raporun hedeflediği kitle tarafından kabul edilir bir formatta yapılandırılmasını ve okuyuculara duyarlı olacak şekilde yazılmasını kapsar (Creswell, 2012). Raporlaştırma yaparken araştırma problemi ile sorunun açık ve anlaşılır bir şekilde tanımlanması; hipotez ile veri toplama, sınama ve yorumlamanın sağlanması ve araştırma modeli ile bilimsel bilginin elde edilmesinde verilerin toplanması ve çözümlenmesi için uygun koşulların düzenlenmesi bir araştırmanın sonucunun ve dolayısıyla yapılan çalışmanın güvenilir olması için önemlidir (Benzer, 2016).

Yukarıda belirtilen alanyazın, araştırmalarda bilimsel yöntemi kullanırken izlenmesi muhtemel aşamaların tanımlarını içermektedir. $\mathrm{Bu}$ tanımlamalar belirtilen aşamanın doğru kullanılması adına önemlidir. Öğretmen adaylarının bilimsel yöntem ve bilimsel yöntem aşamalarıyla ilgili bilgi, beceri, görüş ve tutumlarını inceleyen farklı çalışmalar bulunmaktadır. Alanyazın çalışmalarında nicel veya nitel olarak farklı yöntem yaklaşımları uygulanmıştır. Burada yöntem ayrımı yapılmadan çalışmaların kapsamı ve sonuçları bağlamında çalışmalar ele alınmıştır.

Ulaş1labilen çalışmalar genellikle öğretmen adaylarıyla yürütülmüştür. Bir grup çalışma öğretmen adaylarının bilimsel araştırma yeterliliğinin ölçülmesine yönelik tasarlanmıştır. $\mathrm{Bu}$ çalışmalarda; Şahan ve Tarhan (2015) öğretmen adaylarının bilimsel araştırma yeterliliğini gösteren davranış türlerini çoğunlukla sergilediklerini, Ersoy ve Bal-İncebacak (2016) öğretmen adaylarının bilimsel araştırma yöntemleri bağlamında hazırladıkları raporlarda genelde aşamaları başarılı bir şekilde kullandıklarını, Baştürk (2010) bilimsel yöntem aşamalarını ayrı ayrı ele alırken; öğretmen adaylarının en çok zorlandıkları aşamaları sonuçların tartışılması ve yeni önerilerin getirilmesi, zorlanmadıkları kısımları ise veri toplama araçlarının belirlenmesi, yöntemin belirlenmesi ve verilerin analizi kısımlarında olduklarını, Benzer (2016) öğretmen adaylarının korelasyonel çalışmalarda problem ve hipotez belirlemede başarılı olurken nedensel karşılaştırma, tarama ve deneysel araştırma desenlerinde problem ve hipotez belirlemede yanlışlıklar yaptıklarını, Odabaşı, Kuzu, Kuzu ve Şahin (2011) öğretmen adaylarının alanyazına ulaşmada sıkıntı çekmediklerini, amaçları güzel ifade ettiklerini, konu ve başlıkla uyumlu olduğunu, daha çok anket görüşme ve gözlem formu kullandıklarını ve kaynaklarını APA 5'e göre yazdıklarını tespit etmişlerdir. Küçükoğlu, Taşgın ve Çelik (2013) ise çalışmalarında öğretmen adaylarının bilimsel araştırmalara yönelik kavramlar hakkındaki bilgilerini incelemişler ve bu kavramların tam ve doğru olarak tanımlanamadığını tespit etmişlerdir.

Öğretmen adaylarının bilimsel araştırma yöntemlerine yönelik tutumlarını inceleyen çalışmalarda; Korkmaz, Şahin ve Yeşil (2011a) bilimsel araştırmalara ilişkin tutumları tüm faktörler açısından yüksek bulurken Polat (2014) ve Ayaydın ve Kurtuldu (2010) ise orta düzeyde olumlu bulmuşlardır. 
Bilimsel araştırma yöntemlerine yönelik öğretmen adaylarının görüşlerinin incelendiği çalışmalarda; Akgün'ün (2012) yaptığı çalışmada ilköğretim matematik öğretmen adayları, BAY dersinin kendilerine pek fazla bir katkısı olmadığını dolayısıyla bu dersin gereksiz olduğunu belirtmişlerdir. Korkmaz, Şahin ve Yeşil (2011b) yaptıkları çalışmada öğretmenlerin üçte biri kendini bilimsel araştırmalarda yeterli görürken, üçte biri görmediğini belirtmişlerdir. Küçükoğlu ve diğerleri (2013) öğretmen adaylarının, öğretmenlerin araştırma yapmalarının gerekli olduğunu düşünmedikleri, buna karşın bilimsel araştırmaların meslek hayatlarında işlerine yarayacağını düşündüklerini belirlemiştir.

Bilimsel araştırma yöntemleriyle ilgili farklı amaç ve kapsamda yapılan diğer çalışmalar ise şu şekilde özetlenebilir: Çoğaltay (2016) yaptığı çalışmada BAY dersinin öğretmen adaylarının bilimsel araştırmalara yönelik olumlu tutum düzeylerinde pozitif yönlü anlamlı bir değişime neden olduğunu bulmuş; fakat cinsiyet, branş ve lisedeki mezun olunan alana göre herhangi istatistiksel anlamlı bir farklılığa rastlamamıştır. Kurt, İzmirli, Fırat ve İzmirli (2011) ise kız öğrencilerin erkek öğrencilere, not ortalaması yüksek öğrencilerin not ortalaması düşük öğrencilere, üst sınıftaki öğrencilerin ise alt sınıftaki öğrencilere göre bilimsel araştırma yöntemleri dersine ilişkin daha olumlu görüşe sahip olduğunu tespit etmişlerdir. Taşdemir ve Taşdemir (2011) çalışmalarında Türkçe öğretmeni adaylarının bilimsel bir araştırma raporunun, başl1k/yazar, özet, kaynaklar ve yazma/sunum ile ilgili boyutlarda yüksek düzeyde inceleme yapabildikleri görülürken, giriş, yöntem, bulgular ve sonuç/tartışma boyutlarda bu düzey daha düşük kalmıştır. $\mathrm{Bu}$ sonuçlar öğrencilerin bilimsel araştırmaları daha çok biçimsel yönüyle incelediklerini göstermektedir. Ayrıca, öğrencilerin dokümanları incelendiğinde nicel araştırma desenlerini kullanan çalışmaların ağırlıklı olarak yer aldığı belirlenmiştir.

Odabaşı ve diğerleri (2011) yukarıda belirtilen tüm aşamalarla donatılan öğretmenlerin öğrencilerine de benzer yeterlilikleri kazandıracağ 1 , bu sebeple de öğretmen yetiştirme programlarında bilimsel araştırma yöntemlerinin kazandırılması ile ilgili yeniden düzenlemeye yönelik çalışmaların ivme gösterdiğini belirtmiştir. Tomakin (2007) ve Benzer (2016) bilimsel araştırma yöntemlerinin öğretmen adayları için öğretmen olduklarında eylem araştırması yapabilmeleri için de önemli olduğunu vurgulamışlardır. Benzer'e (2016) göre eğitimde bilimsel araştırma basamakları sadece bilim insanlarının veya akademisyenlerin kullandıkları beceriler olmayıp hayatı anlamak ve karşılaşılan sorunların çözümü için de herkesin ihtiyaç duyacağ becerilerdir. Ayrıca bu becerilerin kazandırılmasında da öğretmenlerin önemli bir etkiye sahip oldukları bir gerçektir. Özellikle konu içeriği itibariyle fen bilgisi öğretmenlerinin bu becerilere sahip olmaları önemlidir. Bu bağlamda çalışma fen bilgisi öğretmen adaylarının bilimsel yöntemi kullanmaları için gerekli olan basamakları nasıl kullandıklarını ortaya koymak adına önemlidir. Buradan hareketle çalışmanın amacı fen bilgisi öğretmen adaylarının kendi belirledikleri problem cümlesinden yola çıkarak her bir bilimsel araştırma yöntemi aşamasını kendisinin oluşturmasıyla hazırladıkları raporlardan hareketle bilimsel araştırma yöntem basamaklarını nasıl kullandıklarını incelemek olarak belirlenmiştir. Bu doğrultuda da problem cümlesi olarak "Fen bilgisi öğretmen adaylarının eğitimde bilimsel araştırma yöntemlerini kullanma düzeyleri nedir?" ifadesi belirlenmiştir.

\section{Yöntem}

Fen bilimleri öğretmen adaylarının eğitimde bilimsel araştırma yöntemlerini ne düzeyde kullandıklarını belirlemek için yapılan bu çalışmada kullanım düzeylerini ortaya çıkarmak için tarama modeli kullanılmıştır. Bu desen sosyal bilimlerde ve sosyolojide çok yaygın kullanılan veri toplama tekniklerinden biridir ve birçok farklı alanda kullanılmaktadır (Kuş, 2012). Tarama modelleri, geçmişte ya da halen var olan bir durumu var olduğu şekliyle betimlemeyi amaçlayan araştırma yaklaşımlarıdır (Köse, 2013). Tarama modeli kapsamında öğretmen adaylarının bilimsel araştırma yöntem basamaklarını ne düzeyde kullandıkları incelenmiş ve her bir araştırma basamağını nasıl kullandıklarını betimlemek için öğrenci raporlarından alıntılara yer verilmiş ve betimsel çözümlemeler yapılmıştır.

\section{Çalışma grubu}


Çalışmada öğretmen adaylarının bilimsel araştırma yöntemi basamaklarını uygulamalarına yönelik bir değerlendirme yapıldığı için "Bilimsel Araştırma Yöntemleri" dersini alan tüm fen bilgisi öğretmen adayları çalışma kapsamına alınmıştır. Bununla birlikte zaman, ulaşım bakımından tasarruf sağlamak ve uygulamanın sürdürülebilirliği adına örnekleme yöntemi olarak uygun örneklem tercih edilmiştir. Çalışma İstanbul'da bir devlet üniversitesinde 2017-2018 güz yarıyılında64 öğretmen adayıyla gerçekleştirilmiştir. Adayların 59'u kadın, 5'i erkek ve 54'ü üçüncü sınıf iken 10'u dördüncü sınıftır. Öğretmen adaylarının raporları kodlanmıştır. Araştırma raporları AR şeklinde grup numaraları ile kodlanmıştır.

\section{Veri toplama araçları}

Çalışmada öğretmen adaylarının eğitimde bilimsel araştırma yöntemlerini kullanabilmeleri için öncelikle öğretmen adaylarına dönem boyunca bilimsel araştırmalarda kullanılan her bir aşama hakkında Bilimsel Araştırma Yöntemleri dersi kapsamında seminer verilmiştir. Bu seminerler haftada 2 ders saati olmak üzere 10 hafta sürmüştür. Seminer derslerinde; bir araştırmada giriş bölümünü oluşturma (alanyazın taraması, problem durumunun ve problem cümlesinin oluşturulması, araştırma soruları, sınırlılıklar ve varsayımların belirlenmesi), eğitim araştırmalarında kullanılabilecek yöntemler (Nicel ve nitel araştırma yöntemleri, desenler), her bir yöntem desenleri için geçerlik ve güvenirlik uygulamaları, örneklem ve evren, veri toplama araçlarının hazırlanması, uygulanması ve değerlendirilmesi, bulguların hazırlanması, raporlaştırma, kaynak yazımı ve etik ihlaller, APA yazım kuralları hakkında etkileşimli bir sunu araştırmacılardan biri tarafından yapılmıştır.

Seminer dersleri sonrasında öğretmen adaylarından kendi istedikleri kişilerle üç ve altı kişi arasında değişen gruplar oluşturarak kendi seçtikleri problem cümlesi üzerinden bilimsel araştırma yöntemlerini dikkate alarak bir araştırma raporu hazırlamaları istenmiştir. Bu süreçte problem seçimi, probleme uygun yöntemin belirlenmesi gibi aşamalarda araştırmacılardan biri öğretmen adaylarına rehberlik etmiştir.

Öğretmen adaylarının fen eğitimi alanında kendi belirledikleri problemden hareketle hazırladıkları araştırma raporları verilerin temel kaynağını oluşturmuştur. Bu raporların iki farklı şekilde veri kaynağı olarak kullanılması söz konusudur. Aşağıda bu husus belirtilmiştir.

\section{Bilimsel Araştırma Yöntemini Kullanma Becerileri Rubriği}

Öğretmen adaylarının bilimsel yöntemin basamaklarını hangi düzeyde ve nasıl kullandıklarını belirlemek amacıyla araştırmacılar tarafından geliştirilen "Bilimsel Araştırma Yöntemini Kullanım Becerileri Rubriği (BAYBeR)" kullanılmıştır. Rubriğin geliştirilme süreci şu şekilde yürütülmüştür; Öncelikle bilimsel araştırmalarda yöntem kavramı ve eğitim araştırmalarında genelde hangi yöntem basamaklarının yer aldığı ve bu basamaklarda yapılması gereken önemli etmenler çeşitli kaynaklardan araştırılmıştır (Baştürk, 2010; Büyüköztürk ve diğerleri, 2018; Creswell, 2012; Ersoy ve Bal İncebacak, 2016; Odabaşı ve diğerleri, 2011). Yapılan araştırmalar neticesinde 41 maddeden oluşan bir havuz oluşturulmuştur. Madde havuzu eğitim araştırmaları alanında uzman üç öğretim üyesi tarafından incelenerek kapsam geçerliliği sağlanmıştır. Bu süreçte, öğretim üyelerinin uzlaşma sağladıkları maddeler aynen kalırken bazı maddeler rubrikten çıkarılmış, bazı maddeler birleştirilmiş, bazıları iki farklı maddeye ayrılmış ve bazı maddeler ise rubriğe eklenmiştir.

Rubriğin içerik ve kapsamı incelendikten sonra bir dil uzmanı öğretim üyesi tarafindan maddelerin anlaş1lırlığı ve dil bilgisi kurallarına uygunluğu incelenmiştir. Bu noktada tüm maddelerin aynı ifade kalıbında olması sağlanmıştır. Ayrıca güvenirliği artırmak amacıyla bir ölçme ve değerlendirme uzmanı ölçek maddelerini ifadeler açısından inceleyerek dönütler vermiştir. Rubriğin güvenirliğinin belirlenmesi için son aşamada daha önceki yıllarda hazırlanan beş araştırma raporu BAYBeR ile araştırmacılardan ikisi tarafindan bağımsız olarak değerlendirilmiştir. Üçüncü araştırmac1, yapılan bağımsız değerlendirmeleri doğrulaması amacıyla önce değerlendirme dışında bırakılmış, diğer iki araştırmacının bağımsız değerlendirmelerinden sonra üçüncü araştırmacı da yapılan değerlendirmeye katılmıştır. Değerlendirme sonucunda Miles ve Huberman'in (1994) önerdiği uzman görüşü/görüş birliği 
formülü kullanılarak rubriğin güvenirliği tespit edilmiştir. Formül şu şekildedir; Güvenirlik=(Görüş Birliğii)/(Görüş Birliği + Görüş Ayrılığı). Formülde görüş birliği; araştırmacıların tüm raporlar için aynı puanı verdikleri madde sayısını, görüş ayrılığ puan verilen madde sayısını temsil etmektedir. Buna göre görüş birliği 131/(131+14) $=0,90$ olarak bulunmuştur. $\mathrm{Bu}$ değer araştırmanın güvenirliği için kabul edilebilir bir değerdir (Miles ve Huberman, 1994).

Yukarıda söz edildiği şekilde hazırlanan BAYBeR öğretmen adaylarının hazırladığ 15 araştırma raporunu değerlendirmek suretiyle veri değerlendirme aracı olarak kullanılmıştır.

\section{Öğretmen adaylarının araştırma raporları}

Bilimsel araştırma yöntemlerine göre hazırlanan araştırma raporları BAYBeR için kaynak sağlamakla birlikte öğretmen adaylarının hangi aşamalarda bilimsel yöntemi nasıl kullandıklarını sergilemek, rubrikten elde edilen sonuçları örneklendirmek ve betimsel bir çözümlemede bulunmak için de kullanılmıştır.

\section{Verilerin analizi \\ BAYBeR ve Araştırma Raporlart}

Her bir grup için ayrı ayrı BAYBeR hazırlanmış ve toplam 15 araştırma raporu BAYBeR'e göre puanlandırılmıştır. Bu puanlandırma iki araştırmacı tarafından bağımsız olarak yapılmıştır. Üçüncü araştırmacı bağımsız karşılaştırmaları doğrulamak için değerlendirmeye katılmıştır. 15 grup için yapılan değerlendirmede uyuşum yüzdesi 78,62 olarak bulunmuştur. Değerlendirmede her bir madde için maddenin raporda bulunup bulunmadığı, yanlış olup olmadığı, zayıf, kabul edilebilir ya da tam yapılma durumuna göre puan verilmiştir. Yapılan puanlandırma şöyledir: Raporda bulunmuyorsa veya yanlışsa 0 , madde zayıf bir şekilde raporda yer almışsa 1, kabul edilebilirse 2, tam olarak yer verildiyse 3 puan şeklindedir. Elde edilen bulgular tablo, açıklama ve öğretmen adaylarının raporlarından doğrudan örneklerle sunulmuştur. Tablolarda; bilimsel araştırma yöntem basamaklarını gösteren maddeler, öğretmen adaylarının her bir maddeyi raporlarında hangi seviyede kullandıklarını gösteren puanlar ve bu puanlara yönelik sıklık ve maddelerden alınan ortalama puanlar verilmiştir. Her bir tablonun ardından sunulan bulgular açıklanmıştır. Bununla birlikte her bir madde için araştırma raporunda çoğunlukla bulunan ve/veya aykırı olan kullanımlar örneklendirilmiştir. Örneklendirmelerde 15 rapor için yanlış ve zayıf olarak değerlendirilen örneklerden alıntılar yapılmıştır. Böylece örneklerden hareketle verilmesi beklenen cevaplar da ifade edilmiştir.

Raporlar değerlendirilirken her bir rapor benzerlik yüzdesi veren bir programda incelenmiş ve bu programdan çıkmış hali üzerinden değerlendirme yapılmıştır. $\mathrm{Bu}$ sayede raporlarda kaynak gösterilmeden kullanılan yerler çalışma kapsamından çıkarılmıştır. Raporlarda uygunsuz kaynak kullanımına yönelik değerlendirme kaynaklarla ilgili maddelerde ayrıca yapılmıştır. Kaynak gösterilerek kullanılan bilgiler ise ne kadar çok kaynak kullanıldı̆̆ 1 ya da kendi çalışmanın özünden yararlanılıp yararlanılmadığı da dikkate alınarak değerlendirilmiştir.

\section{Bulgular}

Öğretmen adaylarının hazırladıkları araştırma raporları araştırmanın amacı doğrultusunda bilimsel araştırma yöntemlerinin aşamaları göz önünde bulundurularak aşama aşama sunulmuştur. Buna göre bulgular; genel görünüş, giriş bölümü, yöntem bölümü, bulgular bölümü, sonuç ve öneriler bölümü ve kaynakça bölümü olmak üzere altı bölüm halinde düzenlenmiştir. Araştırma raporu sayısı 15 olduğu için her bir bölümde alınan puanların sıklığı 15 üzerinden değerlendirilmiştir. Ortalama puanlar ise her bir maddeden alınabilecek en yüksek puan olan üç puan üzerinden değerlendirilmiştir.

\section{Genel görünüş bölümü ile ilgili bulgular}

Genel görünüş bölümünde; araştırma raporunun başlığı, özeti, yazım kuralları ve dil ve anlatım kuralları değerlendirilmiştir. Yapılan değerlendirmeden hareketle edinilen bulgular Tablo 1'de yer almaktadır. 
Tablo 1.

Bilimsel Araştırma Raporlarındaki “Genel Görünüş” Bölümüne Yönelik Bulgular

\begin{tabular}{|c|c|c|c|c|c|c|c|}
\hline \multirow{2}{*}{\multicolumn{2}{|c|}{ BAYBeR Maddeleri }} & \multicolumn{5}{|c|}{ S1kl1k } & \multirow{2}{*}{$\begin{array}{r}\text { Ort. } \\
\text { Puan } \\
(\mathrm{X}<3)\end{array}$} \\
\hline & & Yok & Yanlış & Zayif & $\begin{array}{r}\text { Kabul } \\
\text { edilebilir }\end{array}$ & Tam & \\
\hline 1 & Başlığın içeriği yansıtması & 0 & 1 & 2 & 3 & 9 & 2,33 \\
\hline 2 & $\begin{array}{l}\text { Özetin çalışmayı (amaç, yöntem, } \\
\text { bulgular ve sonuç) kapsaması }\end{array}$ & 0 & 1 & 3 & 4 & 7 & 2,13 \\
\hline 3 & $\begin{array}{l}\text { Belirtilen şablona (biçime) } \\
\text { uyulması }\end{array}$ & 0 & 1 & 1 & 3 & 10 & 2,47 \\
\hline & $\begin{array}{l}\text { Dil ve anlatım kurallarına } \\
\text { uyulması }\end{array}$ & 0 & 0 & 4 & 4 & 7 & 2,20 \\
\hline
\end{tabular}

Tablo 1'de görüldüğü üzere araştırma raporlarında verilen şablona uyulması ve başlı̆̆ın içeriği yansıtması büyük çoğunlukla tam puan almıştır. Ortalama puanlara bakıldığında maddelerin en yüksek puan ortalamasından başlayarak; belirtilen şablona uyulması $(X=2,47)$, başlığın yapılan çalışmayı yansıtması $(X=2,33)$, dil ve anlatım kurallarına uyulması $(X=2,20)$ ve özetin çalışmayı kapsaması $(\mathrm{X}=2,13)$ şeklinde sıralandığ görülmektedir. Bununla birlikte genel görünüş kapsamında değerlendirilen dört maddenin de ortalama puanlarının kabul edilebilir olarak belirlenen 2 puanın üzerinde olduğu tespit edilmiştir.

Araştırma raporlarından hareketle her bir maddeye ilişkin yapılan puanlamalara yönelik örneklere Tablo 2'de bire bir alıntılarla yer verilmiştir.

Tablo 2.

Bilimsel Araştırma Raporlarındaki “Genel Görünüş” Bölümüne Yönelik Bulgular İçin Örnekler

\begin{tabular}{|c|c|c|}
\hline $\begin{array}{l}\text { Rubrik } \\
\text { Madde } \\
\text { Nu. }\end{array}$ & Yanlış & Zayıf \\
\hline 1 & $\begin{array}{l}\text { Fen bilgisi dersinde ortaokul } \\
\text { öğrencilerine verilen ödevlerin } \\
\text { başarılarına etkileri ile ilgili araştırma } \\
\text { Bu araştırmanın amacı ortaöğretim } \\
\text { 8.sınıf ögrencilerinin fen ve teknoloji } \\
\text { dersinde verilen ev ödevleri hakkındaki } \\
\text { tutumlarını araştırmaktır. (AR4) }\end{array}$ & $\begin{array}{l}\text { Is1-sıcaklık konusundaki kavram } \\
\text { yanılgıları } \\
\text { Bu araştırma, 8. Sınıf öğrencilerinin 1s1- } \\
\text { sıcaklık konusu ile ilgili kavram } \\
\text { yanılgılarını belirlemek amacıyla } \\
\text { yapılmıştır. (AR5) }\end{array}$ \\
\hline 2 & $\begin{array}{l}\text { Mevsimsel grip her yaşta insanı } \\
\text { etkileyen gerekli önlemler alınmadığı } \\
\text { takdirde ölümcül olabilen bulaşıcı bir } \\
\text { hastalıktır. Grip aşısı bu hastalığın } \\
\text { tedavisinde özellikle risk grupları için } \\
\text { önemli olan bir etkendir. Bu hastalık ve } \\
\text { tedavisi hakkında bilgi sahibi olmak } \\
\text { önemlidir. Bu çalışma Fen Bilgisi } \\
\text { öğretmen adaylarının grip ve grip aşısı } \\
\text { hakkındaki bilgi düzeylerini ve } \\
\text { tutumlarını araştırmak için yapılmıştır. } \\
\text { (AR13) }\end{array}$ & $\begin{array}{l}\text { Çalışmada öğretmen adaylarının öz } \\
\text { yeterlikleri ve beceri düzeyleri farklı } \\
\text { değişkenlere göre incelenmiştir. } \\
\text { Arastırmada, ilişkisel tarama modeli ve } \\
\text { içerik çözümleme deseni kullanılmıştır. } \\
\text { Örneklem 2017-2018 öğretim yılında... } \\
\text { Fen Bilgisi Öğretmenliği 3. Sınıf } \\
\text { öğrencilerinden oluşmaktadır. Veri } \\
\text { toplama aracı olarak birinci bölümde } \\
\text { kişisel bilgiler, ikinci bölümde ... ölçeği } \\
\text { kullanılmıştır. Araştırma sonucunda elde } \\
\text { edilen veriler içerik çözümleme tablosu ve } \\
\text { SPSS } 15 \text { programında pearson korelasyon } \\
\text { ve betimsel istatistik kullanılarak } \\
\text { çözümlenmiştir. (AR10) }\end{array}$ \\
\hline
\end{tabular}




\begin{tabular}{|c|c|c|}
\hline 3 & $\begin{array}{l}\text { Araştırma raporu şablonunda verilen } \\
\text { başlık sıralamaları ve sayfa düzeni (iki } \\
\text { yana yasla, punto, satır aralığı gibi } \\
\text { bilgiler) dikkate alınmamış ve } \\
\text { karıștırılmıștır. (AR13) }\end{array}$ & $\begin{array}{l}\text { Sayfa düzeni (iki yana yasla, punto, satır } \\
\text { aralı̆̆g gibi bilgiler) dikkate alınmamıştır. } \\
\text { (AR15) }\end{array}$ \\
\hline 4 & - & $\begin{array}{l}\text {...Yani çocuk problem çözme, eleştirel } \\
\text { düşünme, yaratıcllı, sorgulama gibi } \\
\text { becerileri bu süreçte kazanmaya başlıyor. } \\
\text { STEM modeli her ne kadar öğrenci } \\
\text { merkezli bir model olsa da, çocuğun } \\
\text { problemi çözme aşamalarında öğretmenin } \\
\text { bu süreci iyi takip etmesi ve öğrenciye } \\
\text { doğru basamakları izlemesi konusunda } \\
\text { yardım etmesi gerekiyor. Diğer önemli } \\
\text { nokta ise STEM modelinde disiplinler } \\
\text { arası iş birliğidir. } \\
\text {...küresel değerlendirme sınav } \\
\text { sonuçlarında da artış olduğu görülmüş. } \\
\text { Bundan dolayı birçok ülke STEM } \\
\text { modelini eğitim sistemine entegre etmiş } \\
\text { durumda. (AR1) }\end{array}$ \\
\hline
\end{tabular}

'Başlığın içerikle uyumu' maddesinde yanlış olarak örneklenen araştırma raporunda başlıkta "ödevlerin öğrenci başarısına etkisi” ifade edilmiştir; ancak içerikte amaç olarak "ev ödevleri ile ilgili 8. Sınıf öğrencilerinin tutumlarını araştırmak" belirlenmiş ve yöntemde de bu amaca yönelik uygulama yapılmıştır. Zaylf kategorisindeki örnekte ise kavram yanılgılarının hangi sınıf seviyesinde bakılacağına ilişkin bilgiye başlıkta yer verilmemiştir.

'Özetin çalışmayı kapsaması' durumuna ilişkin yanlış kategorisindeki araştırma raporunda sadece çalışmanın konusuyla ilgili genel bir giriş yapıldıktan sonra amaç verilmiş ve özet tamamlanmıştır. Zayıf kategorisindeki örnekte ise raporda bulgular ve sonuçtan bahsedilmemiştir.

'Belirtilen biçime uyulması' maddesinde öğretmen adaylarına araştırma raporlarını hazırlarken kullanmaları için hazır olarak verilen dosya biçimi ve düzeninin genel olarak doğru kullanıldığı görülmüştür. Doğru olmayan kullanıma yönelik verilen örnekte, araştırma raporunda bilimsel araştırmanın basamaklarına dikkat edilmediği, karışık yazıldığı ve biçimsel yazım özelliklerine uyulmadığı, zayıf olarak değerlendirilen raporlarda ise iki yana yasla, punto, satır aralığı gibi sayfa düzeni özelliklerinin dikkate alınmadığı tespit edilmiştir.

'Dil ve anlatım' yönünden yanlış yazılmış raporlar olmamakla birlikte zayıf bir dilin kullanımına yönelik Tablo 2'de verilen örnekte "yani, başlıyor, gerekiyor, görülmüş" gibi akademik dilde kullanılmayan kelime ve yüklem ifadeleri görülmektedir. Bu durum raporun genelinde görülmemesine karşın bilimsel bir dilin kullanımı anlamında zayıflık olarak görülmüştür.

\section{Giriş bölümü ile ilgili bulgular}

Giriş bölümünde; problem durumu ve alanyazın taraması, amaç, önem, sınırlılıklar ve varsayımlar değerlendirilmiştir. Yapılan değerlendirmeden hareketle edinilen bulgulara Tablo 3'te yer verilmiş̧tir.

Tablo 3.

Bilimsel Araştırma Raporlarındaki “Giriş” Bölümüne Yönelik Bulgular

\begin{tabular}{lll}
\hline BAYBeRMaddeleri Siklik & Ort.
\end{tabular}




\begin{tabular}{llrrrrrr}
\hline & Yok & Yanlış & Zayıf & $\begin{array}{r}\text { Kabul } \\
\text { edilebilir }\end{array}$ & Tam & $\begin{array}{r}\text { Puan } \\
(\mathrm{X}<3)\end{array}$ \\
\hline 5 & Problemin açık ve anlaşı1ır olması & 4 & 0 & 1 & 2 & 8 & 1,93 \\
\hline 6 & Amacın anlaşılır olması & 0 & 0 & 2 & 2 & 11 & 2,60 \\
\hline 7 & $\begin{array}{l}\text { Problemle ilgili kuramsal bilgilerin } \\
\text { bütünlük içinde sunulması }\end{array}$ & 0 & 0 & 7 & 6 & 2 & 1,67 \\
\hline 8 & $\begin{array}{l}\text { Problemle ilgili alanyazının eleştirel } \\
\text { bir bakış açısıyla irdelenmesi }\end{array}$ & 6 & 0 & 6 & 3 & 0 & 0,80 \\
\hline 9 & $\begin{array}{l}\text { Araştırmanın gerekçeleriyle birlikte } \\
\text { öneminin vurgulanması }\end{array}$ & 3 & 0 & 6 & 5 & 1 & 1,27 \\
\hline 10 & $\begin{array}{l}\text { Çalışmanın sinırlılıklarının } \\
\text { belirtilmesi }\end{array}$ & 5 & 0 & 2 & 2 & 6 & 1,60 \\
\hline 11 & $\begin{array}{l}\text { Çalışmanın varsayımlarının } \\
\text { belirtilmesi }\end{array}$ & 7 & 0 & 0 & 5 & 3 & 1,27 \\
\hline
\end{tabular}

Araştırma raporlarının giriş kısmı ile ilgili maddeler incelendiğinde öğretmen adaylarının 2,60 ortalama puanla araştırmanın amacını belirlemede başarılı oldukları söylenebilir. Diğer maddelere bakıldığında ise kabul edilebilir olarak değerlendirilen 2 puan ortalamasına hiçbir maddenin ulaşamadığ görülmektedir. Raporlarda en başarısız olan kısım ise 0,80 ortalama puanla alanyazının eleştirel bir bakış açısıyla yazılması aşamasıdır. Bu maddeyi 1,27 ortalama puanla araştırmanın öneminin belirtilmesi ve varsayımlarda bulunma kısımları izlemektedir.

Araştırma raporlarından hareketle her bir maddeye ilişkin yapılan puanlamalara yönelik örneklere aşağıdaki Tablo 4’te birebir alıntılarla yer verilmiştir.

Tablo 4.

Bilimsel Araştırma Raporlarındaki “Giriş” Bölümüne Yönelik Bulgular İçin Örnekler

\begin{tabular}{|c|c|c|}
\hline $\begin{array}{l}\text { Rubrik } \\
\text { Madde } \\
\text { Nu. }\end{array}$ & Yanlış & Zayıf \\
\hline 5 & - & $\begin{array}{l}\text { Fen Bilgisi öğretmen adaylarının web } 2.0 \text { araçlarını kullanım becerileri } \\
\text { yeterli düzeyde midir? (AR10) }\end{array}$ \\
\hline 6 & - & $\begin{array}{l}\text { Çalışmamızda, sigara ile ilgili kamu spotlarının insanlar üzerindeki etkisi } \\
\text { araştırılmış ve sigara içen insanların hayatlarında davranışsal değişikliklere } \\
\text { neden olup olmadığı ortaya konulmaya çalışılmıştır. (AR2) }\end{array}$ \\
\hline 7 & - & $\begin{array}{l}\text {...Her çocuğa hitap etmek neredeyse imkânsızdır. Okul ortamları yeteri } \\
\text { kadar ilgi ve yeteneklerine imkân sağlamamaktadır. Öğrencilerin keyifli } \\
\text { zaman geçirebileceği, dikkatlerinin dağılmadığı, verimli eğitimin } \\
\text { gerçekleştiği ortamlar hazırlanmalıdır. Bu ortamlar öğrencilerin ilgi duyduğu } \\
\text { atmosfere dönüştürülebilir. Öğrencilerin standart sınıf ortamları değil de } \\
\text { hayallerindeki ve ilgi duyabileceği ortamlar oluşturulmalıdır. Ancak belli } \\
\text { yaş gruplarındaki çocukların sevebileceği ortak renkler ortak oyunlar tespit } \\
\text { edilebilir. Bunlar eğitim görülen ortamda belli yerlerde kullanıldığında daha } \\
\text { verimli bir ortam oluşturulabilir. Finlandiya eğitim sisteminde Türk eğitim } \\
\text { sisteminden çok farklı bir eğitim uygulanmaktadır... (AR6) }\end{array}$ \\
\hline 8 & - & $\begin{array}{l}\text {...Aynı zamanda öğrencilerin kendi yaşamlarındaki olay veya olguları } \\
\text { öğrendiği fen bilgileriyle ilişkilendirebilme becerisi kazanması, anlamlı } \\
\text { öğrenmeyi ve öğrencinin fene karşı daha iyi bir bakış açısı kazanarak fen } \\
\text { dersine karşı olumlu bir tutum edinmesini sağlar. Oysa daha önce yapılan } \\
\text { günlük yaşam üzerine olan çalışmalarda sonuçların istenen düzeyde } \\
\text { olmadığg görülmüştür. (AR8) }\end{array}$ \\
\hline
\end{tabular}




\begin{tabular}{lll}
\hline & - & $\begin{array}{l}\text { Bu araştırma öğrencilerin ilgilerini önemli bir çevre sorunu olan küresel } \\
\text { 1sınmaya çekmek ve küresel 1sınmaya ilişkin algılarının ortaya konması } \\
\text { açısından önemlidir. }\end{array}$ \\
& $\begin{array}{l}\text { Çalışmada elde edilen veriler daha sonraki çalışmalar için temel } \\
\text { oluşturulabilir. Fen Bilgisi öğretmenlerine küresel isınmanın öğretimi } \\
\text { konusunda yol gösterici olabilir. (AR7) }\end{array}$ \\
\hline 10 & - & $\begin{array}{l}\text { Araştırma sonucu elde edilen verilerin tek bir üniversiteden elde edilmesi } \\
\text { araştırmanın sınırlılı̆ıdır. (AR13) }\end{array}$ \\
\hline 11 & - & -
\end{tabular}

Tablo 4'e öğretmen adaylarının giriş bölümündeki çalışmalarına ilişkin raporlarının nasıl puanlandığını örneklemek amacıyla yer verilmiştir.

'Problemin açık ve anlaşılır olması' maddesinde yanlış olarak değerlendirilen ifade bulunmamaktadır. Zayıf olarak değerlendirilen problem cümlesine yönelik verilen örnekte ise araştırma raporunda tarama, korelasyonel ve nedensel karşılaştırma yöntemleri birlikte kullanılmasına rağmen problemin sadece tarama desenine uygun bir problem olduğu görülmektedir.

'Amacın anlaşı1ır şekilde belirtilme' durumuna bakıldığında tüm çalışmaların amaç cümlesi içerdiği ve yanlış şekilde kurulmadığı tespit edilmiştir. Kurulum yönünden zaylf olarak değerlendirilen amaç cümlesinin ise çok genel yazıldığı, sigaranın insanlar üzerindeki etkisinden söz ederken hangi yöndeki etkisine bakılacağının belirtilmediği görülmektedir.

'İlgili alanyazın taramasının bütünlük içinde sunulması' maddesinde yanlış kategorisinde değerlendirilen örnek bulunmamaktadır. Zayıf olarak değerlendirilen örnekte, araştırmanın problem cümlesiyle ilgili sınıf ortamları ve öğrenciler hakkında bilgiler verilmiştir; ancak verilen bilgilerin bir bütünlük halinde sunulmadığ 1 , cümleler arasında kopukluklar olduğu görülmektedir.

'Alanyazının eleştirel bir bakış açısıyla irdelenmesi' maddesinde yanlış olarak değerlendirilen bir örnek bulunmamaktadır. Zayıf olarak değerlendirilen örnekte ise alanyazında fen kavramlarının günlük yaşamda kullanılması gerektiği fakat kullanılmadığına yönelik bir eleştiri bulunmaktadır. Ancak bu eleştiri problem durumuyla ilişkilendirilmemiştir.

'Araştırmanın önemiyle ilgili' maddede zayıf olarak değerlendirilen örneğe bakıldığında hangi gerekçelerden dolayı bu araştırmaya ihtiyaç duyulduğuna değinilmediği, araştırmanın yapılmasıyla elde edilecek kazanımların belirtildiği görülmektedir. Ayrıca çalışmanın önemi için doğru veya kabul edilebilir olabilecek ifadeler, farklı kaynaklardan alındığ 1 ve kaynakça gösterilmediği tespit edildiği için kabul edilmemiştir.

'Araştırmada bulunan sınırlılıkların yazımında' sadece çalışma grubuna yönelik sınırlılık belirtildiği için zayıf olarak kabul edilmiştir. Uygulanan ölçme aracı, süre gibi diğer sınırlılıklar belirtilmemiştir.

\section{Yöntem bölümü ile ilgili bulgular}

Yöntem bölümünde; planlanan çalışmanın deseni, çalışma grubu, veri toplama araçları ve değerlendirilmesi ile güvenirlik ve geçerlilik için yapılan işlemler yer almaktadır. Yapılan değerlendirmeden hareketle edinilen bulgulara Tablo 5'te yer verilmiştir.

Tablo 5.

Bilimsel Araştırma Raporlarındaki "Yöntem” Bölümüne Yönelik Bulgular

\begin{tabular}{llllrlr}
\hline & \multicolumn{4}{c}{ Sıklık } & Ort. \\
\cline { 2 - 4 } BAYBeR Maddeleri & Yok & Yanlış & Zayı́ & $\begin{array}{r}\text { Kabul } \\
\text { edilebilir }\end{array}$ & Tam & $(\mathrm{X}<3)$ \\
\hline
\end{tabular}




\begin{tabular}{|c|c|c|c|c|c|c|c|}
\hline 12 & $\begin{array}{l}\text { Çalışmanın deseninin problemi } \\
\text { çözecek nitelikte olması }\end{array}$ & 0 & 0 & 3 & 6 & 6 & 2,20 \\
\hline 13 & $\begin{array}{l}\text { Amaca göre evren ve } \\
\text { örneklem/çalışma grubu seçilmesi }\end{array}$ & 0 & 0 & 2 & 4 & 9 & 2,47 \\
\hline 14 & $\begin{array}{l}\text { Örneklemin özelliklerinin } \\
\text { belirtilmesi }\end{array}$ & 1 & 0 & 2 & 5 & 7 & 2,20 \\
\hline 15 & $\begin{array}{l}\text { Veri toplama aracının/araçlarının } \\
\text { araştırmanın amacına uygun olması }\end{array}$ & 0 & 0 & 1 & 6 & 8 & 2,47 \\
\hline 16 & $\begin{array}{l}\text { Veri toplama araçlarının geçerlik } \\
\text { çalışmalarının belirtilmesi }\end{array}$ & 4 & 0 & 5 & 1 & 5 & 1,47 \\
\hline 17 & $\begin{array}{l}\text { Veri toplama araçlarının güvenirlik } \\
\text { çalışmalarının belirtilmesi }\end{array}$ & 6 & 0 & 4 & 0 & 5 & 1,27 \\
\hline 18 & $\begin{array}{l}\text { Veri toplama aşamalarının } \\
\text { belirtilmesi }\end{array}$ & 6 & 0 & 4 & 2 & 3 & 1,13 \\
\hline 19 & $\begin{array}{l}\text { Verilerin uygun değerlendirme } \\
\text { teknikleriyle yapilmas1 }\end{array}$ & 0 & 0 & 2 & 2 & 11 & 2,60 \\
\hline
\end{tabular}

Bir araştırma raporu hazırlarken yöntem kısmında olması gereken maddelere yönelik araştırma raporlarından elde edilen veriler değerlendirildiğinde; verilerin uygun değerlendirme yöntemleriyle yapılması kısmının 2.60 gibi yüksek bir ortalamayla yapıldığı görülmektedir. $\mathrm{Bu}$ maddeyi 2,47 ortalamayla veri toplama araçlarının ve çalışma grubunun amaca uygun bir şekilde seçilmesi maddeleri izlemektedir. Yöntem kısmında öğrencilerin en zayıf oldukları kısımlar ise verileri toplarken hangi aşamaları izlediklerinin anlatılması $(\mathrm{X}=1,13)$ ve veri toplama araçlarının geçerlik $(\mathrm{X}=1,47)$ ve güvenirlik $(\mathrm{X}=1.27)$ çalışmalarının yapılması kısımları olmuştur.

Araştırma raporlarından hareketle her bir maddeye ilişkin yapılan puanlamalara yönelik örneklere aşağıdaki Tablo 6' da bire bir alıntılarla yer verilmiştir.

Tablo 6.

Bilimsel araştırma raporlarındaki "yöntem" bölümüne yönelik bulgular için örnekler

\begin{tabular}{|c|c|c|}
\hline $\begin{array}{l}\text { Madde } \\
\text { Nu. }\end{array}$ & Yanlış & Zayıf \\
\hline 12 & - & $\begin{array}{l}\text { Marmara Üniversitesi ve Yıldız Teknik Üniversitesi fen bilgisi öğretmenliği } \\
\text { 3.sınıf öğrencilerinin kavram yanılgılarını belirlemek ve karşılaştırmak } \\
\text { amacıyla bu çalışma nicel araştırma temellidir. Yapılan araştırma nedensel } \\
\text { karşılaştırmadır. Böylece iki üniversitedeki kavram yanılgılarının ne } \\
\text { düzeyde olduğu belirlenir ve karşılaştırma yapılır. (AR3) }\end{array}$ \\
\hline 13 & - & $\begin{array}{l}\text { Bu çalışmada örneklem grubu olarak ‘ } \ldots \text { ortaokulu ' } 8 \text {-C' sınıfına } \\
\text { uyguladık. Sınıfımızda } 9 \text { kız öğrenci } 13 \text { erkek öğrenci bulunmaktadır. } \\
\text { (AR4) }\end{array}$ \\
\hline 14 & - & $\begin{array}{l}\text {...̈̈rneklemi ise ... Ortaokulundaki 7.sınıflardan rastgele seçilen } 24 \text { kişilik } \\
\text { bir sınıf oluşturmaktadır. (AR9) }\end{array}$ \\
\hline 15 & - & $\begin{array}{l}\text {... Nicel araştırma yöntemlerinden tarama yöntemini kullandık. } \\
\text { Öğrencilerin ev ödevleri hakkındaki tutumlarını belirlemek için de anket } \\
\text { uyguladık. } \\
\text { Öğrencilerin Fen ve Teknoloji dersinde verilen ev ödevine karşı tutumlarını } \\
\text { ölçmek için } 9 \text { cümleden oluşan ev ödevi tutum anketi uygulandı. (AR4) }\end{array}$ \\
\hline 16 & - & $\begin{array}{l}\text {... olan soruları görüntünün incelenmesi, teknik bilgi ve terimler, kesit alma } \\
\text { ve kullanıldığı sektörler diye } 4 \text { temaya ayırdık. ... görüntünün incelenmesi } \\
\text {... teknik bilgi ve terimler temasına aittir... (AR12) }\end{array}$ \\
\hline
\end{tabular}




\begin{tabular}{lll}
\hline 17 & - & $\begin{array}{l}\text { Araştırma kapsamında, 1s1 ve sıcaklık konusu hakkında öğrencilerin kavram } \\
\text { yanılgılarını tespit etmek amacıyla uzman görüşü alınarak ‘Isı ve Sicaklık } \\
\text { Kavram Yanılgı Testi' geliştirdik... (AR5) }\end{array}$ \\
\hline 18 & - & $\begin{array}{l}\text {..Araştırmanın ilk aşamasında öğrencilere 'Okul dışı bir ortamda eğitim } \\
\text { görme şansınız olsaydı nerede görmek isterdiniz? Resmediniz. ' diye } \\
\text { soruldu. Daha sonra 7 tane sınırlayıcı açı uçlu soru yöneltildi. (AR6) }\end{array}$ \\
\hline 19 & MKBÖ’den elde edilen veriler incelenmiş ve tablolaştırılmıştır. (AR12) \\
\hline
\end{tabular}

Tablo 6'ya öğretmen adaylarının yöntem bölümündeki çalışmalarına ilişkin raporlarının nasıl puanlandığını örneklemek amacıyla yer verilmiştir. Raporlarda incelenen maddeler için yanlış değerlendirme bulunmamaktadır. Zayıf değerlendirilen raporlara yönelik örnekler aşağıdadır.

'Çalışma deseninin problemle uyumunun' incelendiği maddede verilen örnekte öğretmen adaylarının kavram yanılgılarını tespit etmek için nicel araştırma deseni kullandıkları ve nedensel karşılaştırma yaptıkları görülmektedir. Kavram yanılgılarının tespiti için nitel çalışmaların yapılmasının daha uygun olacağı düşünülmektedir. $\mathrm{Bu}$ sebeple tasarım zaylf olarak değerlendirilmiştir.

'Örneklem ve evrenin amaca uygun olarak seçilmesi' ile ilgili verilen örnekte genelleme amacı güden ve tarama yöntemi ile yürütülen bir çalışmada örneklemin çok az kişi ile yürütüldüğü görülmektedir. 'Örneklemin özelliklerini belirtildiği' maddede ise sadece sınıf düzeyi ve katılan sayısı belirtilirken, katılımcıların diğer özellikleri belirtilmediği için zayıf kategorisinde değerlendirilmiştir.

'Veri toplama aracının araştırmanın amacına uygunluğunda' nicel araştırmalardan tarama deseninin kullanıldığı bir çalışmada veri toplama aracı olarak kullanılan anketin öğrencilerin ödevlere yönelik tutumlarını ölçmek için içerik olarak zayı $f$ olduğu/kapsam geçerliliğinin düşük olduğu görülmüştür.

'Ölçme aracının geçerliliği' ile ilgili verilen örnekte öğrencinin sadece içerik ile ilgili temaları verdiği görülmektedir. Bu bir ölçme aracının geçerliliğinin belirlenmesinde yeterli görülmemektedir. Ölçme aracının güvenirliği için öğretmen adayları uzman görüşünden bahsetmişlerdir. Bir uzmanın görüşünü almak yeterli görülmemekte bunun yerine birkaç uzmandan görüş alınarak uyuşum yüzdesinin hesaplanması uygun değerlendirilmektedir.

'Veri toplama aracının uygulanması' ile ilgili aşamalara bakıldığında ölçme aracının uygulanması için verilen süreye çoğu araştırma raporunda yer verilmediği görülmüş̧ür. Bununla birlikte açık uçlu soruların öğrencilere nasıl uygulandığından bahsedilmemiştir. Bu sebeplerle verilen örnek, zayıf olarak değerlendirilmiştir.

'Verilerin uygun değerlendirme teknikleriyle yapılmasıyla' ilgili zayı kategorisi için verilen örnekte verilerin incelenip tablolar şeklinde sunulduğundan söz edilmiş; ancak nasıl bir çözümleme yapıldığından bahsedilmemiştir.

\section{Bulgular bölümü ile ilgili bulgular}

Bulgular bölümünde; bulguların araştırma sorularına göre anlaşılır bir şekilde sunulması, tablo ve şekillerin biçim ve anlaşılırlığı ile bulguların yorumlanması kısımları yer almaktadır. Bu bölümle ilgili elde edilen bulgular Tablo 7'de verilmiştir.

Tablo 7.

Bilimsel Araştırma Raporlarındaki “Bulgular” Bölümüne Yönelik Bulgular

\begin{tabular}{|c|c|c|c|c|c|c|c|}
\hline \multirow{2}{*}{\multicolumn{2}{|c|}{ BAYBeR Maddeleri }} & \multicolumn{5}{|c|}{ Siklik } & \multirow{2}{*}{$\begin{array}{r}\text { Ort. } \\
\text { Puan } \\
(\mathrm{X}<3) \\
\end{array}$} \\
\hline & & Yok & Yanlış & Zayıf & $\begin{array}{r}\text { Kabul } \\
\text { edilebilir }\end{array}$ & Tam & \\
\hline 20 & $\begin{array}{l}\text { Araştırma sorularına göre } \\
\text { bulguların sunulması }\end{array}$ & 0 & 0 & 4 & 4 & 7 & 2,20 \\
\hline
\end{tabular}




\begin{tabular}{|c|c|c|c|c|c|c|c|}
\hline 21 & $\begin{array}{l}\text { Tablo ve şekillerin verilerinin } \\
\text { anlaşıllır bir şekilde sunmas }\end{array}$ & 0 & 0 & 1 & 6 & 8 & 2,47 \\
\hline 22 & $\begin{array}{l}\text { Tablo ve şekillerin } \\
\text { adlandırmasının tablodaki verileri } \\
\text { (değişkenleri) yansıtması }\end{array}$ & 3 & 0 & 0 & 4 & 8 & 2,13 \\
\hline 23 & $\begin{array}{l}\text { Bulguların, tablo ve şekillerin } \\
\text { yorumlanması }\end{array}$ & 3 & 0 & 2 & 3 & 7 & 1,93 \\
\hline
\end{tabular}

Tablo 7'de görüldüğü gibi bulgular kısmı genel anlamda kabul edilebilir puan ortalaması olan iki puan civarında bulunmaktadır. Tablo ve şekiller hakkında açıklama yapılmasına ilişkin madde diğer maddelere göre nispeten biraz daha düşük puan ortalamasına sahiptir $(X=1,93)$.

Araştırma raporlarından hareketle her bir maddeye ilişkin yapılan puanlamalara yönelik örneklere aşağıdaki Tablo 8'de bire bir alıntılarla yer verilmiştir.

Tablo 8.

Bilimsel Araştırma Raporlarındaki “Bulgular” Bölümüne Yönelik Bulgular İçin Örnekler

\begin{tabular}{|c|c|c|}
\hline $\begin{array}{l}\text { Madde } \\
\text { Nu. }\end{array}$ & Yanlış & Zayif \\
\hline 20 & - & $\begin{array}{l}\text { 'İlkokul 3. Sınıf öğrencilerinin fene yönelik alg1 ve görüşleri nelerdir? } \\
\text {..."Fen kavramlarının analizi"... "Günlük hayatta fenin kullanımı"..."Fenin } \\
\text { kullanımına yönelik görüşler"... (AR11) }\end{array}$ \\
\hline 21 & - & 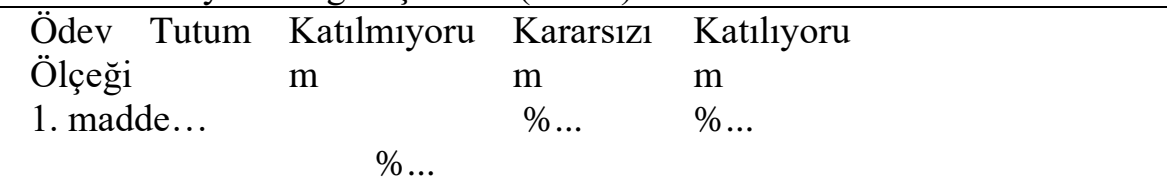 \\
\hline 22 & - & - \\
\hline 23 & - & $\begin{array}{l}\text {.. } \\
\text { Sicaklık nedir sorusunu yanlış cevaplayanların çoğu sıcaklığın ölçüm } \\
\text { olduğunu söylemiş ve } 1 \text { sı kavramı ile karıştırmışlardır (AR5) }\end{array}$ \\
\hline
\end{tabular}

Tablo 8'e öğretmen adaylarının ‘bulgular' bölümündeki çalışmalarına ilişkin raporlarının nasıl puanlandığını örneklemek amacıyla yer verilmiştir. Her bir madde için yanlış yapılan örnek bulunmadığı için sadece zayıf olarak değerlendirilen örneklere yer verilmiştir.

'Bulguların araştırma sorusu ya da sorularına göre sunulmasına' yönelik araştırma raporlarından verilen örnekte, ilk önce problem daha sonra bulgulardaki başlıklar verilmiştir. Başlıklarda araştırma sorusunda olmayan bulgular da bulunmaktadır.

'Tablo ve şekillerin verileri anlaşı1ır bir şekilde sunması' ile ilgili verilen örnekte tabloda satır aralıklarına dikkat edilmediği, kelimelerin bazı harflerinin düzensiz bir şekilde yarım bırakıldığı ve hiç kenarlık kullanılmadığı görülmektedir.

'Tablo ve şekillerin adlandırmasının tablodaki verileri (değişkenleri) yansıtması' ile ilgili yanlış veya zaylf örnek bulunmamaktadır.

'Bulguların yorumlanmasına' ilişkin öğretmen adaylarının raporlarından alınan örnekte, tablolarda fazlaca veri bulunmasına rağmen sadece yanlış cevaplardan bir örnekten söz edilmiş olduğu ve sayısal veri veya diğer bulgulardan söz edilmediği görülmektedir.

\section{Sonuç ve öneriler bölümü ile ilgili bulgular}

Sonuç ve öneriler bölümünde araştırma sorularına göre ulaşılan sonuçların verilmesi ve bu sonuçların farklı kaynaklarla tartışılması, araştırma bulgularından beslenen önerilerin getirilmesi kısımları bulunmaktadır. Tablo 9'da bu kısımla ilgili bulgulara yer verilmiştir.

Tablo 9. 
Bilimsel Araştırma Raporlarındaki “Sonuç Ve Öneriler” Bölümüne Yönelik Bulgular

\begin{tabular}{|c|c|c|c|c|c|c|c|}
\hline \multirow{2}{*}{\multicolumn{2}{|c|}{ BAYBeR Maddeleri }} & \multicolumn{5}{|l|}{ Siklık } & \multirow{2}{*}{$\begin{array}{r}\text { Ort. } \\
\text { Puan } \\
(\mathrm{X}<3)\end{array}$} \\
\hline & & Yok & Yanlış & Zayıf & Kabul & Tam & \\
\hline 24 & $\begin{array}{l}\text { Sonucun araştırma sorularına } \\
\text { göre yap1landırılması }\end{array}$ & 0 & 1 & 0 & 8 & 6 & 2,27 \\
\hline 25 & $\begin{array}{l}\text { Sonuçların ilgili } \\
\text { alanyazındaki kaynaklarla } \\
\text { tartış1lması }\end{array}$ & 7 & 0 & 2 & 4 & 2 & 1,07 \\
\hline 26 & $\begin{array}{l}\text { Araştırma sonuçlarına dayalı } \\
\text { olarak yeni önerilerin } \\
\text { geliştirilmesi }\end{array}$ & 0 & 1 & 4 & 9 & 1 & 1,67 \\
\hline
\end{tabular}

Araştırma raporlarının sonuç ve öneriler kısmıyla ilgili bulgular incelendiğinde; öğretmen adaylarının 'araştırma sorusu/sorularına göre sonucu yapılandırdığı' görülmektedir $(\mathrm{X}=2,27)$. Ancak raporlarda 'yapılandırılan sonuçların alanyazındaki diğer kaynaklarla tartışılması' kısmı zayıf seviyede kalmıştır $(\mathrm{X}=1,07)$. Bu kısımda araştırma raporlarının yarısına yakınında sonuçları tartışmak için herhangi bir kaynak kullanmadığ 1 görülmektedir $\left(\mathrm{n}_{\text {yok }}=7\right)$. Araştırma sonuçlarına dayalı olarak yeni önerilerin geliştirilmesi maddesinde de öğretmen adaylarının önerilerinin zayıf düzeyde kaldığı bulunmuştur $(X=1,67)$.

Araştırma raporlarından hareketle her bir maddeye ilişkin yapılan puanlamalara yönelik örneklere aşağıdaki Tablo 10'da bire bir alıntılarla yer verilmiştir.

Tablo 10.

Bilimsel Araştırma Raporlarındaki "Sonuç Ve Öneriler" Bölümüne Yönelik Bulgular İçin Örnekler

Madde Yanlış $\quad$ Zayıf

$\mathrm{Nu}$.

$\mathrm{Bu}$ çalışmanın temel amacı ev

ödevlerinin öğrencinin başarısına

katkısını araştırmaktı.

Araştırmada probleme çözüm bulmak amaçlanmıştır.

24 Öğrencilere verilen ödevler onların bilgi seviyesine uygun olmalidır.

Seviyenin altında olursa öğrenciler zaten

o konuyu biidiklerinden önemsemeden

ve düzensiz bir şekilde yapacaklardır.

(AR4)

...Bu konuyla ilgili yapılan diğer araştırmaların sonuçlarının incelenmesi (COŞTU, AYAS, ÜNAL ,Mart, 2007), (AYDOĞAN,GÜNEŞ,GÜLÇIÇEK, 2003) ile kurmuş olduğumuz hipotez, yapmış olduğumuz çalışmamızda gerek ögrencilerin tutumu gerekse okulun kalitesi, çevre şartları, öğretmenin yeterlilikleri ve daha birçok etkenden dolay1 \%41,27'lik bir kavram yanılgısının varlığı ile net olarak doğrulanamamıştır. Almış olduğumuz örneklemden yola çıkarak öğrencilerde 


\begin{tabular}{|c|c|c|}
\hline & & $\begin{array}{l}\text { yüksek oranda kavram yanılgıs1 } \\
\text { görülmemiştir... (AR5) }\end{array}$ \\
\hline 26 & $\begin{array}{l}\text { İnternet bilgiye erişmede işlerimizi } \\
\text { zaman ve mekânda tasarruf ederek } \\
\text { kolaylaştırmaktadır. "Önemli olan } \\
\text { interneti aşırıya kaçmadan ve bağımlılık } \\
\text { oluşturmadan işlevsel olarak } \\
\text { kullanmaktır. Ayrıca internet, günlük } \\
\text { işlemlerin takibi, bilgi erişimi araştırma } \\
\text { inceleme yapma, ödev hazırlama, } \\
\text { duygusal olarak gerginliklerin } \\
\text { giderilmesi ve serbest zamanı } \\
\text { değerlendirme gibi etkinliklerde } \\
\text { kullanılabilir. Bu etkinliklerde dikkat } \\
\text { edilmesi gereken interneti amacına } \\
\text { uygun ve işlevsel olarak } \\
\text { kullanmaktır.”(Selçuk üniversitesi } \\
\text { sosyal bilimler enstitüsü dergisi } \\
\text { 21/2009). (AR15) }\end{array}$ & $\begin{array}{l}\text { Fen öğretiminde görev alan } \\
\text { öğretmenlerin bu alanda ki bilgi ve } \\
\text { becerilere sahip olması gerektiği } \\
\text { düşünüldüğ̈̈nde; öğretmen adaylarının } \\
\text { hizmet öncesi dönemde aldıkları } \\
\text { eğitimlerinde, konuların günlük yaşamla } \\
\text { ilişkilendirildiği örneklerin ayrıntılı } \\
\text { olarak işlenip olayların nedenlerinin } \\
\text { sorgulandığı seçmeli ya da zorunlu bir } \\
\text { dersin konulmasının uygun olduğu } \\
\text { düşünülmektedir... (Ahi Evran } \\
\text { Üniversitesi Kırşehir Eğitim Fakültesi } \\
\text { Dergisi (KEFAD) Cilt 8, Sayı 1, (2007) } \\
\text { 205) (AR9) }\end{array}$ \\
\hline
\end{tabular}

'Araştırma sorularına göre sonucun yapılandırılma' durumu için yanlış kategorisinde incelenen örnekte, araştırmanın amacının yer aldığı; fakat sorulara veya probleme göre sonucun verilmesi yerine doğrudan önerilerden bahsedildiği görülmektedir.

'Sonuçların ilgili alanyazındeki kaynaklarla tartışılması' maddesinde öğrencilerin çoğunun tartışmada hiç kaynak kullanmadıkları ya da kullandıkları kaynaklarla tartışma yapamadıkları verilen örnekte görülmektedir. Bu madde ile ilgili zayıf kategorine örnek olarak sunulan araştırma raporunda öğretmen adayı sonuç ile ilgili kaynak kullanmış, bu kaynakla sonucunu ilişkilendirmeye çalışmış; fakat kendi bulduğu sonucu neden desteklediğine/desteklemediğine, yönelik bir açıklamada bulunmamıştır.

'Araştırma sonuçlarına dayalı olarak yeni önerilerin geliştirilmesi' maddesinde yanlış olarak puanlanan örnekte; internetin öneminden söz edilmiş, nasıl kullanılması gerektiğine yönelik bir kaynaktan bilgi verilmiş ancak araştırma bulgularına yönelik bir öneri, hatta herhangi bir öneri verilmemiştir. Zayıf olarak değerlendirilen örnekte ise araştırma bulgularından beslenen bir öneri yerine farklı bir kaynaktan genel olarak kullanılan bir öneri ifade edilmiştir.

\section{Kaynakça bölümü ile ilgili bulgular}

Kaynakça bölümünde metin içi ve metin dışı kaynak gösterimlerinin APA'ya uygunluğu ve yayın etiğine uyulması kısımları yer almaktadır. Yapılan incelemeler sonucunda ulaşılan bulgulara Tablo 11'de yer verilmiştir.

Tablo 11.

Bilimsel Araştırma Raporlarındaki "Kaynakça” Bölümüne Yönelik Bulgular

\begin{tabular}{llrrrrrr}
\hline \multirow{2}{*}{ BAYBeR Maddeleri } & \multicolumn{9}{c}{ Sıklık } & $\begin{array}{r}\text { Ort. } \\
\text { Puan } \\
(\mathrm{X}<3)\end{array}$ \\
\hline 27 & $\begin{array}{l}\text { Metin içi kaynak gösteriminin } \\
\text { APA kurallarına uygun yazılmas }\end{array}$ & 1 & 2 & 4 & 4 & 4 & 1,60 \\
\hline 28 & $\begin{array}{l}\text { Yayın etiği kurallarına uyularak } \\
\text { alıntıların yapılmış olması }\end{array}$ & 0 & 9 & 2 & 2 & 2 & 0,80 \\
\hline 29 & $\begin{array}{l}\text { Kaynakçanın APA stilinde } \\
\text { yazılması }\end{array}$ & 2 & 3 & 3 & 5 & 2 & 1,27 \\
\hline
\end{tabular}


Bilimsel araştırma raporlarında kaynakça bölümünün yazımına bakıldığında araştırma raporlarının her bir maddede zaylf düzeyde kaldığı ortalama puanlardan görülmektedir. Kaynakça bölümünde en başarısız kalan madde ise yayın etiği kurallarına uyularak metin içi veya metin sonu kaynak gösteriminin yapılmış olmasıdır $(\mathrm{X}=0,80)$.

Araştırma raporlarından hareketle her bir maddeye ilişkin yapılan puanlamalara yönelik örneklere Tablo 12'de birebir alıntılarla yer verilmiştir.

Tablo 12.

Bilimsel Araştırma Raporlarındaki "Kaynakça” Bölümüne Yönelik Bulgular İçin Örnekler

\begin{tabular}{|c|c|c|}
\hline $\begin{array}{l}\text { Madde } \\
\text { Nu. }\end{array}$ & Yanlış & Zayıf \\
\hline 27 & $\begin{array}{l}\text {...STEM, bu tarihten itibaren hızlı bir } \\
\text { şekilde yayılmıştır (STEM eğitim ve } \\
\text { mühendislik uygulamalarının fen } \\
\text { bilgisi laboratuvar dersindeki } \\
\text { etkinliklerin incelenmesi, Bekir } \\
\text { YILDIRIM, Yusuf ALTUN). (AR1) }\end{array}$ & $\begin{array}{l}\text {... bundan sonraki araştırmalara bir örnek } \\
\text { teşkil etmesinin de önemli olduğu } \\
\text { vurgulanmalıdır. (Yaman, Göçkan, 2015) } \\
\text { (AR2) }\end{array}$ \\
\hline 28 & $\begin{array}{l}\text {... sözlü sunumlara göre daha } \\
\text { ekonomiktir (Horzum, 2010). Kolay } \\
\text { erişilebilir, az ve öz olma gibi birçok } \\
\text { faydas1 bulunmaktadır (Geoghegan ve } \\
\text { Klas, 2007). (AR10) }\end{array}$ & $\begin{array}{l}\text { "Aslında çocuklar, okulların gerçek } \\
\text { sahibidirler. Kendileriyle ilgili sorunlarda, } \\
\text { en isabetli çözümler, yine çocukların ve } \\
\text { gençlerin kendilerince bulunabilir. Okulda } \\
\text { gelişim düzeylerine uygun olarak kendi } \\
\text { sorunlarıyla ilgili söz ve yetki sahibi olan } \\
\text { çocuk kendi öğrenme süreçlerine ve } \\
\text { okuluna, bunun bir uzantısı (devamı) olarak } \\
\text { da, yetişkinlikte toplumsal sorunlarına aktif } \\
\text { şekilde sahip çıkacaktır." (MEB, 2013; } \\
\text { UNICEF, 2013). (AR6) }\end{array}$ \\
\hline 29 & $\begin{array}{l}\text { KAYNAKÇA: } \\
\text { Serkan AYDOĞAN, Bilal GÜNEŞ, } \\
\text { Çağlar GÜLÇIÇEK, G.Ü. Gazi } \\
\text { Eğitim Fakültesi Dergisi Cilt 23, Sayı } \\
2 \text { (2003) 111-124 } \\
\text { Bayram COŞTU, Alipaşa AYAS, } \\
\text { Suat ÜNAL,Mart 2007 Cilt:15 No:1 } \\
\text { Kastamonu Eğitim Dergisi 123-136 } \\
\text { (AR6) }\end{array}$ & $\begin{array}{l}\text { Fatme Seçgin, Gamze Yalvaç, Turhan } \\
\text { Çetin. (2010). İlköğretim 8. Sınıf } \\
\text { Öğrencilerinin Karikatürler Aracılığıyla } \\
\text { Çevre Sorunlarına İlişkin Algılar, Gazi } \\
\text { Üniversitesi Eğitim Fakültesi } \\
\text { Fikri Pekel, Özgecan Taştan Kırık. (2016). } \\
\text { Middle School Students' Cognitive } \\
\text { Structures About Global Warming And } \\
\text { Ozone Layer Depletion. 41... (AR7) }\end{array}$ \\
\hline
\end{tabular}

'Metin içi kaynak gösteriminin APA kurallarına uygun yazılması' maddesi için sunulan örneklere bakıldığında; kullanılan kaynağın eser adı ve yazarların ad-soyadlarının verilmesi, yayın tarihinin verilmemesi yanlış olarak değerlendirilmiştir. Zayıf örnekte ise kullanım genel itibari ile doğru olmakla birlikte yazar soyadlarının 've' bağlacı ile belirtilmesi gerekliliği bakımından zayıf olarak nitelendirilmiştir.

'Yayın etiği kurallarına uyularak alıntıların yapılmış olması' maddesinde yanlış örnekte başka bir kaynaktan alındığı tespit edilen yabancı makaleler direkt asıl kaynaktan alınmış şekilde, aktaran olmadan/okunan kaynağa yer vermeden kullanılmıştır. Zaylf örnekte ise tırnak işareti ile verilen bir kaynağın sadece bir kaynağa ait olması gerekirken MEB ve UNICEF birlikte kullanılmıştır. Burada hangisinin aktardığı belli değildir.

'Kaynakçanın APA stilinde yazılması' maddesinde yanlış örnekte kaynak olarak kullanılan çalışmaların adlarının verilmediği, kaynakça gösteriminin APA'ya uygun olmadığ görülmektedir. Ayrıca bu örnekte metin içi kaynakların da hepsinin kaynakçada verilmediği ve 
sadece iki kaynak yazıldığı tespit edilmiştir. Zayıf örnekte ise kullanılan kaynaklara ait bilgiler bulunmakta ancak sadece eksiklikler ve ufak hataların olduğu görülmektedir.

\section{Tartışma, Sonuç ve Öneriler}

Bilimsel bilgiye ulaşma yolunda ilk ciddi adımlarını atmaları için öğrencilerine yardımcı olacak fen bilgisi ögretmen adaylarının bu yolda kendilerinin attıkları adımları tespit etmek için yapılan bu çalışmada aşağıdaki sonuçlara ulaşılmıştır.

Bilimsel çalışmalarda başlık, biçim, özet, dil ve anlaşılırlık bağlamında ele alınan genel görünüş çerçevesinde değerlendirilen tüm raporların kabul edilebilir seviyenin üstünde olduğu tespit edilmiştir. Ersoy ve Bal İncebacak (2016) yaptıkları çalışmada öğretmen adaylarının raporlarında içerik olarak (başlıklar, punto ve şablon...) raporların çoğunun başarılı olduğu bulunmuş, sadece özet yazımında ihmal olduğu belirtilmiştir. Bu çalışmada da genel görünüş aşamasında kabul edilebilir düzeyde olmasına rağmen en düşük puan özet yazımında görülmüştür. Makalenin çatısını oluşturan özet yazımı (Tiryaki, 2014) makalenin içeriğini daha okumadan okuyucuya ipuçları verir. Altuğ Özsoy'a (1998) göre iyi bir özeti iyi bir makale, kötü bir özeti ise sorunlu bir makale izler. Bu bağlamda bir makalenin vitrini sayılabilecek özet konusunda öğretmen adaylarının diğer genel görünüş maddelerine göre daha az puan seviyesinde kalması farklı nedenlerle açıklanabilir. Lisans eğitimleri sırasında fen bilgisi öğretmen adayları bilimsel yöntemi kullanırken hangi derslerde veya etkinliklerde özet yazımını kullanıyorlardır sorusu akla gelmektedir. Belki de öğretmen adayları birinci sınıfta aldıkları yazılı anlatım dersi haricinde özet yazımıyla ilgili bir ders veya uygulama almamaktadırlar. Çünkü özet yazımı çoğunlukla var olan bir metnin kısaltılması anlamına gelmekte ve üzerine çok düşülmemekte olabilir.

Araştırma raporlarının giriş kısmında öğretmen adaylarının özellikle alanyazında kullandıkları kaynakları eleştirel bir bakış açısıyla yazarken zorlandıkları, hatta bu kısımda zayıf seviyeye bile ulaşamadıkları görülmüştür. Bununla birlikte çalışmanın önemini zayıf bir şekilde açıkladıkları tespit edilmiştir. Bu kısımda öğretmen adaylarının en başarılı oldukları kısım araştırmalarının amacını belirtmek olmuştur. Ersoy ve Bal-İncebacak (2016) yaptıkları çalışmada öğretmen adaylarının tamamının araştırmanın amacını doğru ifade ettiklerini bulmuştur. $\mathrm{Bu}$ durum öğretmenlerin amaç cümlelerini bilimsel araştırma yöntemleri dışında da kurmalarından kaynaklanmış olabilir. Alanyazın araştırması ve yazımı ise lisans eğitiminde hatta tüm eğitim süresince başlı başına bir sorundur. Araştırma ödevlerinin benzerlik yüzdesine veya intihal durumuna bakılmaksızın bile kaynakların sistematik bir şekilde incelenmesi ve birbiriyle bağdaştırılması içinde yedirilmesi, yazımda bütüncül bir akışın sağlanması, bu akışta özgün ifadelere yer verilerek kaynakların tartışılması istenen bir durumken genelde peş peşe kaynak eklenmesi şeklinde raporlar oluşturulmaktadır. Bu durumun sadece lisans seviyesinde alınan eğitimle ilgili olmadığı, küçük yaşlardan itibaren öğrenci ürünlerinin bu bakış açısıyla irdelenmemesi sonucunda lisans eğitiminde karşımıza çıktığı düşünülmektedir.

Raporların yöntem kısmından elde edilen sonuçlarda öğretmen adaylarının en başarılı oldukları kısım veri toplama araçlarının ve değerlendirme yöntemlerinin çalışmaya uygunluğudur. Bunu çalışma grubunun belirlenmesi izlemektedir. Bu kısımlar tam puana yakın bir değer almışlardır. Öğretmen adaylarının verilerin değerlendirilmesi aşamasında genellikle frekans ve yüzde hesaplama şeklinde analiz yaparak daha ileri seviyede analiz yapmamaları nedeniyle bu değerlerin yüksek çıktığı düşünülmektedir. Nitekim Ersoy ve Bal-İncebacak (2016) yaptıkları çalışmada da öğretmen adaylarının bulgularda tamamen yüzde ve frekans kullandıkları, çok az bir kısmının kodlama yaptığını tespit etmişlerdir. Baştürk (2010) öğretmen adaylarının raporlarında en kolay buldukları ve gerçekleştirmede zorlanmadıkları kısımlar olarak veri toplama araçlarının belirlenmesi, araştırma yönteminin seçilmesi ve verilerin uygun bir şekilde analiz edilmesi olarak bulmuştur. Raporların en zayıf oldukları kısımlar ise verilerin nasıl toplandığının ve geçerlik ile güvenirlik çalışmalarının nasıl yapıldığının açıklandığı kısımlar olmuştur. Ersoy ve Bal İncebacak (2016) yaptıkları çalışmada öğretmen adaylarının çok az bir kısmının geçerlik ve güvenirlikten bahsettiğini tespit etmişlerdir. Geçerlik ve güvenirlik bilimsel 
araştırmalarda ve fen bilimlerinin doğasında önemli bir yer tutmasına rağmen öğretmen adaylarının bu maddelerde zayıf olmaları düşündürücüdür.

Raporlarda bulguların yer aldığı kısım, tüm maddeler için kabul edilebilir puan ortalamasında bulunmuştur. Bulgular araştırma sorularına göre sunulmuş, tablolar başlık, içerik ve açıklama olarak kabul edilebilir şekilde hazırlanmıştır. Ersoy ve Bal-İncebacak (2016) da tabloya başlık ekleme, değişkenleri belirleme, yüzde ve aralıkları belirleme ve yorumlama aşamalarında öğretmen adaylarının sıkıntı yaşamadıklarını tespit etmişlerdir.

Araştırma raporlarının sonuç ve öneriler kısmında sonuçların kabul edilebilir oranda araştırma sorusu veya sorularına göre yapılandırıldığı tespit edilmiştir. Sonuçların tartışılması ise çok düşük düzeyde kalmıştır. Bu kısımda raporların yarısına yakını hiçbir kaynak kullanmamış, kullanan raporlar ise sadece bu kaynakların sonuçlarını desteklediğini ifade etmişlerdir. Araștırma sonuçlarına dayalı olarak yeni önerilerin geliştirilmesi maddesinde ise öğretmen adaylarının önerilerinin kabul edilebilir düzeye ulaşamadığı bulunmuştur. Benzer şekilde Baştürk (2010) öğretmen adaylarının hazırladıkları raporların bilimsel araştırma yapma becerileri yönünden en zayıf kaldıkları noktaların elde edilen bulguların ve dolayısıyla sonuçların tartışılması, araştırma sonunda elde edilen sonuçlara göre "yeni önerilerin geliştirilmesi" kısımlarında olduğunu bulmuştur. Sonuç ve öneriler konuyla ilgili çalışmaların bir adım ileri taşınması için önemli bir kısımdır. Yapılan çalışma sonucunda nasıl bir bilimsel bilgi edinildiğinin belirtildiği, bu bilginin farklı kaynaklarla tartışıldığı ve sonuçlardan hareketle başka araştırmalar için öneriler getirildiğ kısımdır. Bu kısımla ilgili yetersizliğin; eğitim boyunca sonuç çıkarmaya dayalı yapılan uygulamaların sonuçlarında genellikle sadece bulguların alt problemlere göre ifade edilerek yazılması pratiğinin daha fazla kullanılması sebebiyle olabileceği düşünülmektedir.

Bilimsel araştırma raporlarında kaynakça bölümünün yazımına bakıldığında araştırma raporlarının her bir maddede zayıf düzeyde kaldığı bulunmuştur. Kaynakça bölümünde en başarısız kalan madde ise yayın etiği kurallarına uyularak metin içi veya metin sonu kaynak gösteriminin yapılmış olmasıdır. Ersoy ve Bal İncebacak (2016) bilimsel araştırmalarda öğretmen adaylarının kaynak kullandığını fakat yarısının doğru kullandığını tespit etmiştir. Toprak (2017) yaptığı çalışmada Türkiye'de yapılmış lisansüstü tezleri incelemiş ve bu tezlerin ortalama benzerlik oranın $\% 28,7$ bulurken, bu tezlerden $\% 34,5$ 'inde intihal olduğunu tespit etmiştir. $\mathrm{Ne}$ yazıkki, bilimsel çalışmalarda sıkça karşılaşılan bu problemin en büyük sebebinin etik eğitimi eksikliğinden kaynaklandığı düşünülmektedir. Öğrencilere benzerlik programının kullanılacağı belirtilmesine rağmen kaynakların beklenen şekilde kullanılmaması bu düşünceyi destekler niteliktedir.

Çalışmadaki tüm aşamalar bir bütün olarak değerlendirildiğinde amacın doğru bir biçimde ifade edilmesi ve verilerin uygun tekniklerle analiz edilmesi kısımları en başarılı kısımlar olurken, alanyazının eleştirel bir bakış açısıyla yazılması, sonuçların farklı kaynaklarla tartışılması ve kaynak yazımında etik kurallara uyulması kısımları en başarısız kısımlar olmuştur. Kart ve Gelbal (2014) ise öğretmen adaylarının bilimsel araştırma becerilerine yönelik öz yeterlik algılarını en yüksek olandan en düşük olana doğru sıraladıklarında, sıralamanın veri toplama, alanyazın/tarama, raporlaştırma, problemi belirleme, araştırma yöntemini belirleme, değişkenleri belirleme ve veri analizi şeklinde olduğu sonucuna ulaşmışlardır. Yapılan araştırma ile belirtilen araştırmanın sonuçları birbirini destekler nitelikte görülmemektedir. Bu sonuçlar göz önüne alındığında bu durumun nedenlerinin araştırılması önemli görülmektedir. Öğretmen adaylarının özellikle kaynak gösterimi ve alanyazın taramasında başarılı olmadıkları halde kendilerini yeterli bulmaları çalışmalardaki örneklemlerin farklılı̆̆ından kaynaklanabilir. $\mathrm{Bu}$ nedenle, aynı örneklemden hareketle bilimsel araştırmalarda özyeterlik ve bilimsel araştırmalarda yeterliğin karşılaştırılacağı bir çalışmanın bu bulguyu açıklamak için faydalı olacağı düşünülmektedir.

Fen bilgisi öğretmenliği lisans programları incelendiğinde 1998 yılında yayınlanan programda bilimsel araştırma yöntemleri ve etik ile ilgili bir dersin olmadığ 1,2006 programında bilimsel araştırma yöntemleri dersinin olduğu ve etik konuların ise kısıtlı bir şekilde bu dersin içeriğinde yer aldığı görülmektedir. İlk defa 2018 yılında yayınlanan programda Eğitim Etiği ve Ahlak dersi zorunlu, bilimsel araştırmalarda etik dersi seçmeli olarak programda yer almıştır. Bu küçük inceleme sadece etik konuların öğretmen eğitimi lisans programlarında ne kadar geç yer 
verildiğini ortaya koymak için yazılmıştır. Buradan hareketle öğretmen eğitiminde etik uygulamaların da içinde bulunduğu bir dersin programa eklenmesinin yararlı olacağı ve öğretim üyeleri için hangi ders olursa olsun öğrenci ödevlerinin, araştırma raporlarının veya projelerinin bu bağlamda titizlikle kontrol edilmesi önerilmektedir.

Özellikle öğrenci ödevlerinin sadece lisans düzeyinde değil daha küçük sınıflarda etik açıdan kontrol edilmesi gerektiği, etik eğitiminin erken çocukluktan itibaren her bir sınıf seviyesine uygun şekilde düzenlenerek programlarda yer alması önerilmektedir. Bununla birlikte tüm öğretim düzeyleri için yapılan incelemelerin, öğrencilerin de yaptıkları hata veya doğrularının farkında olmaları için geri dönütlerle onlarla paylaşılması yararlı olacaktır.

Özellikle fen bilgisi öğretmenliğinde bilimsel araştırma yöntemleri kullanımı önemlidir. Bu sebeple bu ders işlenirken her bir aşamanın uygulamalı ve deneye-yanıla doğruyu bulma esasına uygun olarak öğretim üyesi rehberliğinde yapılması önerilir.

Yapılan bu çalışmada ulaşılan sonuçların fen bilgisi öğretmen adaylarının lisans eğitimlerine bağlı olup olmadığının tespit edilmesi için farklı üniversitelerde bulunan fen bilgisi öğretmen adaylarıyla da benzer bir çalışma yürütülmesi önerilmektedir.

\section{Etik Kurul Onay Bilgileri}

Hasan Kalyoncu Üniversitesi Sosyal Bilimler Enstitüsü, 01.04.2020, say1-804.01.E2004010005.

\section{Kaynaklar}

Akgün, L. (2012). Bilimsel araştırma yöntemleri dersine ilişkin öğretmen adaylarının algı ve beklentileri. Balıkesir Üniversitesi Sosyal Bilimler Enstitüsü Dergisi, 15(27), 21-30.

Altuğ Özsoy, S. (1998). Kısa özet yazımı ve değerlendirilmesi. Ege Üniversitesi Hemşirelik Yüksek Okulu Dergisi, 14(11), 115-118.

Arıkan, R. (2013). Araştırma yöntem ve teknikleri. Ankara: Nobel Yayınevi.

Ayaydın, A. ve Kurtuldu, M.K. (2010). Güzel sanatlar eğitimi bölümü öğrencilerinin bilimsel araştırma yöntemleri dersine ilişkin tutumları. Abant İzzet Baysal Üniversitesi Dergisi, $10(2), 1-8$.

Aziz, A. (2018). Sosyal bilimlerde araştırma yöntemleri ve teknikleri. Ankara: Nobel Yayınc1lık.

Bal, H. (2009). Sosyal bilimlerde nicel araştırma yöntem ve teknikleri. İstanbul: Fakülte Kitabevi Yayınlar1.

Balcı, A. (2015). Sosyal bilimlerde araştırma yöntem, teknik ve ilkeler. Ankara: Pegem Yayınevi

Baştürk, R. (2010). Bilimsel araştırma ödevlerinin çok yüzeyli Rasch ölçme modeli ile değerlendirilmesi. Eğitimde ve Psikolojide Ölçme ve Değerlendirme Dergisi, 1(1), 51-57.

Batı, K. (2013). Fen eğitiminde bilimsel yöntem süreci öğretimi üzerine bir inceleme: Pozitivizmden anarşist bilgi kuramına. Pamukkale Üniversitesi Ĕgitim Fakültesi Dergisi, 34, 211-226.

Benzer, E. (2016). Fen bilgisi öğretmen adaylarının bilimsel araştırmalarda problem, hipotez ve model belirleme durumlarının incelenmesi. The Journal of Academic Social Science Studies, 53, 335-344.

Büyüköztürk, Ş., Çakmak, E., Akgün, Ö., Karadeniz, Ş. ve Demirel, F. (2018). Eğitimde bilimsel araştırma yöntemleri. Ankara: Pegem Akademi Yayınları.

Cemaloğlu, N. (2009). Veri toplama teknikleri: Nicel-nitel.A. Tanrı̈ŏğen (Ed.). Bilimsel Araştırma Yöntemleri içinde. Ankara: Anı Yayıncılık.

Creswell, J.W. (2012). Eğitim araştırmaları. Ş. Tatık, (Bölüm çev., 2017). İstanbul: Edam Yayinevi.

Çoğaltay, N. (2016). Bilimsel araştırma yöntemleri dersinin öğretmen adaylarının bilimsel epistemolojik inançları ve bilimsel araştırmalara yönelik tutumları üzerindeki etkisi. Muş Alparslan Üniversitesi Sosyal Bilimler Dergisi, 4(2), 125-140.

Dura, C. (2005). Düşünme, araştırma ve yazma yöntemleri. Ankara: Ekin Kitabevi.

Düztepe, Ş. (2004). Araştırmalarda bilimsel yöntemin kullanılması ve araştırmanın temel aşamaları. Havacılık ve Uzay Teknolojileri Dergisi, 1(3), 49-53.

Ekiz, D. (2009). Bilimsel araştırma yöntemleri. Ankara: Anı Yayıncılık. 
Erkuş, A. (2011). Davranış bilimleri için bilimsel araştırma süreci. Ankara: Seçkin Yayınc1lık.

Ersoy, E., ve Bal İncebacak, B. (2016). Okulöncesi öğretmen adaylarının bilimsel araştırmaya bakışları. Qualitative Studies (NWSAQS), 11(4), 67-77.

Genç, S.Z. (2013). Bilimsel araştırma basamakları. R.Y. Kıncal (Ed.). Bilimsel Araştırma Yöntemleri içinde. Ankara: Nobel Yayıncılık.

Gürsakal, N. (2001). Ssosyal bilimlerde araştırma yöntemleri. Bursa: Uludağ Üniversitesi Bas.

Karasar, N. (1991). Araştırmalarda rapor hazırlama. Ankara: Sanem Matbaacılık.

Karasar, N. (1998). Bilimsel araştırma yöntemi. Ankara: Nobel Yayınevi.

Kart, A. ve Gelbal, S. (2014). Öğretmen adaylarının bilimsel araştırma öz yeterlik algılarının ikili karşılaştırmalı yargılar yöntemiyle belirlenmesi. Eğitimde ve Psikolojide Ölçme ve Değerlendirme Dergisi, 5(1), 12-23.

Kaya, Z. ve Şahin, M. (2013). Meslek yüksek okullarl için araştırma yöntemleri ve teknikleri. Konya: Eğitim Yayınevi.

Korkmaz, Ö. Şahin, A. ve Yeşil, R. (2011a). Öğretmen adaylarının bilimsel araştırmalara yönelik tutumlar1. International Online Journal of Educational Sciences, 3(3), 1169-1194.

Korkmaz, Ö. Şahin, A. ve Yeşil, R. (2011b). Öğretmenlerin bilimsel araştırmalara ve araştırmacılara iliş̧kin düşünceleri. Kuramsal Eğitimbilim, 4(2), 109-127.

Köse, E. (2013). Bilimsel araştırma modelleri. R.Y. Kıncal (Yay. haz.). Bilimsel Araştırma Yöntemleri içinde. Ankara: Nobel Yayıncılık.

Kurt, A.A., İzmirli, Ö.Ş., Fırat, M. ve İzmirli, S. (2011). Bilimsel araştırma yöntemleri dersine ilişkin bilgisayar ve öğretim teknolojileri eğitimi bölümü öğrencilerinin görüşlerinin incelenmesi. Dumlupınar Üniversitesi Sosyal Bilimler Dergisi, 30, 19-28.

Kuş, E. (2012). Nicel ve nitel araştırma teknikleri. Ankara: Anı Yayıncılık.

Küçükoğlu, A., Taşgın, A. ve Çelik, N. (2013). Öğretmen adaylarının bilimsel araştırma sürecine ilişkin görüşleri üzerine bir inceleme. TSA, 17(3), 11-24.

Miles, M. B. ve Huberman, A. M. (1994). Qualitative data analysis: An expanded sourcebook (2nd edition). California: Sage Publishing.

Odabaşı, F., Kuzu, A., Kuzu, E.B. ve Şahin, Y.L. (2011). Bilişim teknolojileri öğretmeni adaylarının bilimsel araştırma önerisi hazırlama deneyimlerinin yansıtılması. Ahi Evran Üniversitesi Ĕ̈itim Fakültesi Dergisi, 12(2), 41-52.

Özdamar, K. (2003). Modern bilimsel araştırma yöntemleri. Eskişehir: Kaan Kitabevi.

Palmquist, B. C. ve Finley, F. N. (1997). Preservice teachers' views of the nature of science during a postbaccalaureate science teaching program. Journal of Research in Science Teaching, 34(6), 595-615.

Polat, M. (2014). Eğitim fakültesi öğrencilerinin bilimsel araştırmaya yönelik tutumları. Pamukkale Üniversitesi Sosyal Bilimler Enstitüsü Dergisi, 18,77-90.

Saruhan, Ş. ve Özdemirci, A. (2011). Bilim, felsefe ve metodoloji. İstanbul: Beta Yayınları.

Seyidoğlu, H. (2009). Bilimsel araştırma ve yazma el kitabı. İstanbul: Güzem Can Yayınları.

Sönmez, V. ve Alacapınar, F. (2011). Örneklendirilmiş bilimsel araştırma yöntemleri. Ankara: Anı Yayıncilik.

Şahan, H. H. ve Tarhan, R. (2015). Scientific research competencies of prospective teachers and their attitudes toward scientific research. International Journal of Psychology and Educational Studies, 2(3), 20-31.

Şencan, H. (2006). Sosyal ve davranışsal bilimlerde bilimsel araştırma sürecinin temel öğeleri. İstanbul: Bilge Matbaacilık.

Taşdemir, M. ve Taşdemir, A. (2011). Öğretmen adaylarının bilimsel araştırmaları inceleme yeterlikleri. Selçuk Üniversitesi Sosyal Bilimler Enstitüsü Dergisi, 26, 343-353.

Tiryaki, O. (2014). Bilimsel yayın hazırlama teknikleri. ÇOMÜ Ziraat Fakültesi Dergisi, 2(1), 143-155.

Tomakin, E. (2007). Bilimsel araştırma yöntemleri dersinin etkin öğretilmesinin incelenmesi. KKEFD, 16, 37-65.

Toprak, Z. (2017). Türkiye'de akademik yazı: İntihal ve özgünlük. Boğaziçi Üniversitesi Eğitim Dergisi,34 (2), 1-12. 
Yazıcıoğlu, Y. ve Erdoğan, S. (2011). Spss uygulamalı bilimsel araştırma yöntemleri. Ankara: Detay Yayincilik.

Yolcu, H. (2009). Bilimsel araştırmaya ilişkin temel kavramlar. A. Tanrıöğen (Yay. haz.). Bilimsel araştırma yöntemleri içinde. Ankara: Anı Yayıncılık.

YÖK, (2020, 28 Mart). Türkiye yüksek öğretim yeterlilikler çerçevesi. Erişim adresi: http://tyyc.yok.gov.tr/?pid=48

\section{Extended Abstract}

\section{Introduction}

The importance of science and scientific concepts in science education is not only related to scientific knowledge consisting of concepts, theories and laws, but also the theory and how laws are formed for the people who produce, question and solve problems. The attitudes of individuals, and therefore societies, towards science increase the living standards of countries. For this reason, learning and teaching scientific processes are getting more important in national science programs. It is important to help pre-service teachers to acquire these skills since they will be ones who are going to teach them to their students.

Bat1 (2013) stated that an effective science education can be achieved by providing an environment where students can produce free, absurd or irrational ideas and can reach a solution with the methods they have developed themselves without depending on a particular method in accessing information. In this context; It is seen that practice is the most important factor that enables teachers to understand science in the best way.

According to Benzer (2016), acquiring scientific research skills is not only necessary for scientists or academicians, but also for everyone who wants to understand life and solve the problems they face. It is a fact that teachers have an important effect on gaining these skills. Considering the content of the subjects they teach; it is especially important for science teachers to have these skills. Taking this into account, the current study is important in order to reveal to what extend the pre-service science teachers use scientific research methods in classroom activities they prepare.

\section{Method}

The survey model was used to determine to what extend pre-service science teachers use scientific research methods in education. In addition to this, descriptive analysis was used to analyze teacher candidates' reports to find how they use these methods.

Study group: The study was carried out with 64 pre-service science teachers consisting of 59 female and 5 male students. 54 participants were junior and 10 were seniors at university.

Research reports prepared by pre-service teachers were the main source of the data. The pre-service teachers themselves decided on the research topics and developed the research methods. The reports were used for two different purposes. The first aim was to determine to what extend pre-service teachers use the steps scientific method. For this purpose, each report was evaluated with the "Skills Rubric for Using Scientific Research Method (SRUSRM)" developed by the researchers. The second aim was to demonstrate how (well) the pre-service teachers used the scientific methods, to illustrate the results obtained from the rubric, and to make a descriptive analysis.

SRUSRM was prepared for each group of pre-service teachers and 15 research reports were scored according to SRUSRM. This scoring was done independently by two researchers. A third researcher participated in the assessment to verify independent comparisons. The percentage of agreement between the scorers was 78,62. The evaluation was done by scoring each item in the report; whether they were wrong, weak, acceptable or complete. The scoring is as follows: ' 0 'if it is not found in the report or it is wrong, ' 1 'if the item is weakly included in the report, ' 2 ' if it is acceptable, ' 3 'if it is fully included. The findings are presented with tables, explanations and direct examples taken from the pre-service teachers' reports. 


\section{Results and Discussion}

The research reports prepared by preservice teachers were examined in six sections considering the steps of scientific research methods. These were general view, introduction section, method section, findings section, conclusion and suggestions section, and bibliography section. Since there were 15 research reports, the frequency of the scores in each section was evaluated over 15. Mean scores were evaluated based on 3 points, which is the highest score that can be obtained from each item. The findings are as follows:

In the "General view" section; complying with the template given in the research reports and choosing an appropriate title for the study mostly received full points. The results from highest to the lowest score can be summarized as: complying the template $(X=2.47)$, choosing an appropriate title $(X=2.33)$, using appropriate language $(X=2.20)$, and writing a good abstract $(\mathrm{X}=2.13)$.

When the "Introduction" section was analyzed, it was seen that prospective teachers are successful in determining the purpose of the research with an average score of 2.60. When the other items were analyzed, it was seen that no item has reached the average of 2 points, which is considered acceptable. Pre-service teachers do not know how to write a literature review $(\mathrm{X}=0.80)$. Similarly, they cannot state the importance of research $(\mathrm{X}=1,27)$ and make assumptions $(\mathrm{X}=1,27)$.

Analysis of the "Method" section showed that collecting data with appropriate methods was the part the students were most successful at, with an average of 2.60. This item is followed by the choosing appropriate data collection tools and participants according to the purpose, with an average of 2.47 . The weakest points of the students in the method section were writing the steps of the research in detail $(X=1.13)$ and analyzing the validity $(X=1.47)$ and reliability $(\mathrm{X}=1.27)$ of the data collection tools.

Most items in the "Findings" section reached 2 points, which is a generally acceptable level. Only the item explaining the tables and figures appropriately $(X=1.93)$ had a slightly lower score compared to other items.

In the "Results and Suggestions" section; it is seen that pre-service teachers 'interpret the results according to the research question (s)' $(X=2.27)$. However, they cannot 'discuss the results of their findings by comparing with the literature' $(X=1.07)$. It was seen that no references from the literature was used in almost half of the research reports (nnull=7). Moreover, it was observed that the students are not good at suggesting further studies related to their study and findings $(\mathrm{X}=1.67)$.

The results of the study showed that pre-service teachers do not how to cite or give references appropriately, especially how to do an in-text or end-of-text citation ( $\mathrm{X}=0.80)$.

The results of the study showed that pre-service teachers are knowledgeable in writing an abstract, using appropriate language and choosing a suitable title for their study. The analysis of introduction part of the research reports showed that the teacher candidates had difficulties in writing literature review and explaining the importance of the study. However, they were good at stating the purpose of their research. The results obtained from the method section showed that teacher candidates are able to choose data collection tools, participants and evaluation methods appropriately for their study. The reason why the students' scored very high in the analysis part can be related to them doing only the frequency and percentage calculation that is doing only basic analysis. It was also found that the students are good at presenting the results of the study; the answers of the research questions were given appropriately, and the tables and figures were explained well. However, the discussion of the results was weak. The students could not relate their study with the previous ones. Similarly, they were not able to write a good suggestion part. Giving references was the other part weak area they need to study further. Therefore, it can be said that even though the students are good at deciding on the methodology of the study and presenting its results well, they do not know how to do literature review, how to cite and give references, and how to relate their study with the previous ones. Thus, more emphasis should be given to these areas the students are weak in the science education departments. 